\title{
6
}

\section{'Knowledge cost ya nothing and is not heavy to carry around': Taungurung bush tucker, bush medicine and bushcraft}

Uncle Roy held a deep respect for both his grandparents, but a special bond with his grandmother gave him authority as a Taungurung Elder and teacher. At the end of her life, Lizzie Edmond Patterson entrusted young Roy with spiritual custodianship:

On the 12th of February 1950, when I was 91/2 years old, dad came and picked me up out of school and took me down to my grandparents' place. Grandfather grabbed me and took me into the bedroom where Nanna was. She was still in bed, and grandfather put me in the bed beside my grandmother. She put her arms around me, and I put my arm around her, and my grandfather went to the other side of the room. I don't know how long I was there, but after a while grandfather come over and took Nanna's arm off me and took my arm off her and walked me outside. He give me to my mother, and then walked back into the bedroom. A little while later he said 'he's got his grandmother's spirit'. Nanna told 
me about respect, and when she died she gave me her spirit. That was quite a few days ago now. I am proud of it and she is still there today; she is still there within me and she guides me. ${ }^{1}$

This responsibility or mantle, passed from grandmother to grandchild, undergirded Uncle Roy's desire to teach Taungurung history and culture. After our initial meetings, Uncle Roy commented:

I think first we better go up to that bush tucker mob and spend some time up there, so you can actually taste it and feel it firsthand; this is going to open up your eyes darl, I mean it. You see, people think, 'Oh, that's only a weed', but you wait until you taste that weed, it is unreal. I'm goin' to talk about the bush tucker, which I learnt through my grandmother and grandfather mainly. I wasn't very old when it started up, only about 4 or 5 years old. ${ }^{2}$

Uncle Roy makes the important point that plants growing 'wild' in the bush might be mistaken as weeds by the uninformed, but this misnaming does not affect the importance of the plant as tucker. Defining what is or is not a weed is culturally contingent; human-plant interactions are directly influenced by social conceptualisations of vegetation. ${ }^{3}$ Since invasion, the attitudes of European settlers to indigenous vegetation has been shaped by utilitarian, psychological and aesthetic considerations. ${ }^{4} \mathrm{~A}$ preference for open country, neatly tilled fields and familiar European species influenced what Tom Griffiths has described as 'century-scale vegetation change' in Australia. ${ }^{5}$ When Uncle Roy saw introduced species like poplars and willows growing uncontrolled in the bush, he commented that Europeans brought them over to Australia so that they could feel more at home. He asked: 'Why didn't they just stay at home and appreciate them over there?'

\footnotetext{
Roy Patterson, in conversation with Jennifer Jones, 3 March 2016, DS3001137.

Roy Patterson, in conversation with Jennifer Jones, 3 March 2016, DS3001139.

Head and Atchison, 'Cultural Ecology'.

Bonyhady, The Colonial Earth, 78.

Griffiths, 'How Many Trees', 375.
} 


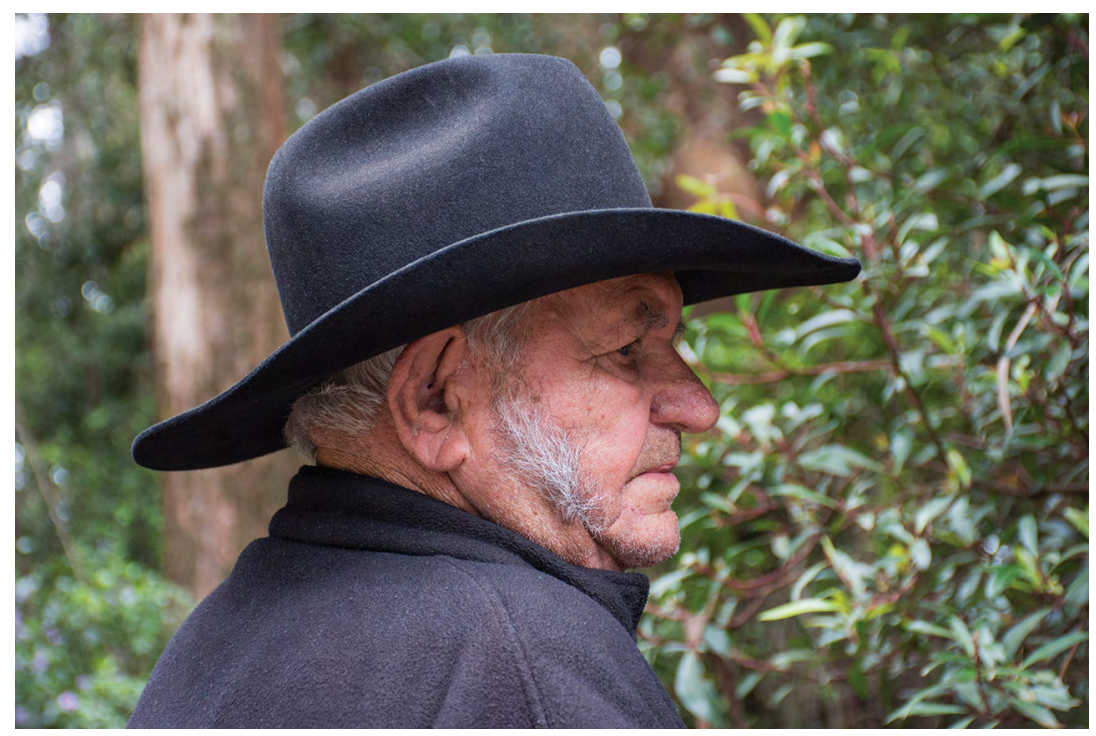

\section{Uncle Roy Patterson}

Source: Photographed by Moorina Bonini.

European attitudes to foraging were also shaped by historic perceptions that sedentary agriculture was progressive and advanced, while huntergatherer societies were unproblematically viewed as backward or primitive. ${ }^{6}$ From this perspective, systematic Aboriginal travel commonly described by the term 'walkabout' was seen as aimless wandering rather than purposeful, systematised and sustainable travel around Country that enabled seasonal management of grains and food plants. ${ }^{7}$ As Indigenous environmental management strategies and systems were not considered to be 'farming', they were dismissed, and existing flora was seen as 'an impediment rather than a resource'. Indigenous plants were removed and replaced in a process described as 'improvement'. ${ }^{8}$ Contemporary non-Indigenous Australian attitudes to plants could be understood as overlaying ancient and continuing Indigenous Australian cultural relationships with food and medical vegetation. Uncle Roy wanted his readers to become sensitive to this context, recognising that development of respectful attitudes will benefit the coexistence of Aboriginal and non-Aboriginal people on the lands they share.

6 Yen, 'The Domestication of Environment'.

7 Kneebone, 'Interpreting Traditional Culture'; Pascoe, Dark Emu.

8 Griffiths, 'How Many Trees', 378. 
The first step towards achieving this understanding was to get into the bush, visiting specific local places at the right time and with the right attitude. Uncle Roy's approach to teaching and learning was process and relationship oriented, rather than focused on an endpoint or outcome. ${ }^{9}$ He took Moorina Bonini, our photographer, and me onto Country so that our learning was experiential and built upon what we already knew. He was always asking us, 'So, what do you want to know?', and helping us to contextualise new experiences by connecting past with present and future.

We set out to our classroom in the rolling hills, river flats and roadside scrub. The stories Uncle Roy shared about bush tucker and bush medicine were intergenerational, emerging from long family relationships with particular places: ${ }^{10}$

On Friday night me grandmother and grandfather come and picked me up from home in the horse and dray. They had a big blue draught horse whose name was Jess. Grandfather never had to hit her or nothing; he'd just say 'shake a leg Jess' and she'd get into a trot. They'd take me down to their place at the end of McGretton's Road in Healesville, and then next day me grandfather and I'd go out with the old tea-tree pole with a piece of string, makin out that we are fishin', and me grandfather is teachin' me. A man cannot teach a woman or a girl, and a woman can't teach a man or a boy; that is our law. That's how I learnt my culture and my Dreamtime, about the spirit world and our law; with me Granddad. ${ }^{11}$

As I accompanied Uncle Roy onto Taungurung Country for the first time, he explained that these gender restrictions did not apply to me, because I am non-Aboriginal. I was certainly aware that I was a rookie. Perched uncomfortably in a new university $4 \mathrm{WD}$, I thought I was creeping along the tracks, concentrating on the potholes, when Uncle Roy would interrupt with an urgent 'slow down, slow down'. Hardly 100 metres past the last cleared paddock, and we were already surrounded by bush tucker and bush medicine.

Uncle Roy came alive in the bush. Alert and attentive, he identified distant specimens for us to find and examine. We were in and out of the car to note the form and texture of plants, to crush, smell and taste.

9 Acton et al., 'Conversations on Cultural Sustainability'.

10 Tuck, McKenzie and McCoy, 'Land Education', 8.

11 Roy Patterson, in conversation with Jennifer Jones, 3 March 2016, DS3001139. 
Uncle Roy's spirit was tireless, but he still had to drag his body in and out of the vehicle. 'Come on you bugger', he would say as he heaved his left leg back into the car again. Moorina and I tried to help, but our efforts were not always welcome.

One time, Uncle Roy spotted the fresh new leaves of a gum tree, up high in a clearing. We headed up the track and pulled the $4 \mathrm{WD}$ in as close as possible. It was difficult terrain. Uncle Roy was out of the car in a flash, and soon tumbling down the hill. Thankfully, an embankment of leaves and bark buffered his fall. Moorina and I were still in shock, as Uncle Roy was brushing dirt from his trousers. Back on task, he looked nonplussed and then annoyed as we fussed over him. He had taken harder falls in his life and wanted us to focus on the next lesson. He continued:

Everything you eat is medicine in our bush tucker; we heal ourselves with what we eat. You can't get nothing better than that. You watch the birds and the animals; what they eat, you can eat. We've got medicine to cure the colds and flu, and it is so simple, it is too easy; but the Europeans have found out about some of our medicine and they are strippin' the trees of it and we get nothing for it. It is our traditional knowledge; most of your medicine in the chemist shop has come from Indigenous knowledge. People say, 'these are only plants!' but they are our food and medicine. ${ }^{12}$

Bush medicine makes use of plants that are abundant in the everyday contexts. Such knowledge has the potential to connect local communities to their natural environments, and to promote respect for local Indigenous people. ${ }^{13}$

In this chapter, Uncle Roy talks about bush medicines that treat a range of ailments, including colds, sore muscles, wounds, headaches and rashes. Uncle Roy treated people in the Taggerty district who came to him for cures. This was his contribution to reconciliation processes:

I do smoking ceremonies for cleansing your spirit. I don't care what colour skin you got; you've got an inner spirit. The smoking is to cleanse and ease the pain of the hurt within the inner spirit. It doesn't cure it, but it does make it easier to live with the hurt. I've got three people that come up every year for smoking. One of

12 Roy Patterson, in conversation with Jennifer Jones, 15 April 2016, DS300143.

13 Ralph-Flint, 'Cultural Borrowing'. 
them is an American lady who sent me a letter from America when her mother was dying; she asked me to send a smoking over. I faced north-west and blew the smoke that way. About a month later, she come home and said she could smell the eucalyptus, and when she smelt that, she saw her mother relax; then she died peacefully. ${ }^{14}$

Uncle Roy viewed 'medical pluralism', or the integration of traditional medical practices with biomedical healthcare, as essential to the preservation of Taungurung culture. Improvements in Indigenous and non-Indigenous health and wellbeing come through connection to Country and culture. ${ }^{15}$ Bush tucker and bush medicine provide a site where 'Indigenous and non-Indigenous worlds of knowledge and experience' can intersect for the benefit of both people and Country. ${ }^{16}$

Animals also provide Taungurung people and newcomers with guidance in our shared environment. Not all views of the world are secular and/or functional, and Uncle Roy wanted to communicate Taungurung understandings that non-human species and their environments should be held with loving regard: ${ }^{17}$

The Dreaming comes into everything, our dancing and corroboree, our walkabout, every part of our lives. My totem is the crow; he is a messenger. The koala, he don't drink water; so we go to the koala to get permission to get good water on our walkabout. If we don't ask for permission, we get bad water. That way, we live in the Dreamtime world as a part of daily life; I still live it today. When I am teaching, I am teaching my Dreaming and through the Dreaming we learn the ways of Mother Earth, the ways of Bunjil and the ways of our people. ${ }^{18}$

Uncle Roy's relationship with Bunjil the eagle had an ecological dimension. Bleakley explained this by noting that human-animal relationships provide 'a focus for a wider explicit sympathy with the world at large'. ${ }^{19}$ Uncle Roy understood that there is a continuity between humans, animals and the world:

14 Roy Patterson, in conversation with Jennifer Jones, 3 March 2016, DS3001137.

15 Oliver, 'The Role of Traditional Medicine'.

16 Nakata, 'Pathways for Indigenous Education'.

17 Rose, 'Love in the Time of Extinctions', 83.

18 Roy Patterson, in conversation with Jennifer Jones, 15 April 2016, DS300142.

19 Bleakley, 'Animals and Information', 132. 
Bunjil is the creator, Bunjil gave life to Mother Earth, to flora and fauna. Bunjil gave us bush tucker, bush medicine and our way of life. They are a beautiful animal and the creator that made us in our Dreamtime. That is why I am so proud of them.

When I go to the Healesville Sanctuary to watch the birds of prey, Bunjil comes up behind me and talks to me, especially one young female eagle. She will not shut up. She is a beautiful bird; I've got one of her feathers at home. The male eagle was shot by the farmer; the wildlife people had to go up and put him out of his misery. When I die, the feathers go to me grandchildren. The feathers carry Bunjil's spirit.

One bloke at the Healesville Sanctuary says to me, 'Uncle, this one Bunjil never stops watchin' you all the time you're with me'. I can rub me hand up and down her chest and she is lovin' it. He says, 'I've never seen her do that'. He said, 'why do you reckon that is Uncle?' I said, 'the spirit of the Aboriginal people'. He says, 'you are probably right'. ${ }^{20}$

Uncle Roy held deep sympathy for Bunjil and their suffering under the impact of colonisation. He observed the eagle's management of a changed diet, and the spiritual haven that both eagle and Aboriginal people find at Camp Jungai:

Whenever an eagle eats rabbit, dead sheep, dead cattle, whatever, the fur goes in down their throat and they get a fur ball. Every now and again they cough the fur ball up. They go down to a special tree at Camp Jungai down by the Rubicon River where they cough up. I do believe when they cough up their fur ball, they cough up part of their spirit and you can actually feel that spirit and the power of it down around those trees. I've had Elders come down from New South Wales and Queensland, and I've taken them down there, and they didn't know our culture or nothing, but they sat down on the ground there and they never moved. They spend the whole day there because they could feel the spirit. I feel it every time I go down there. In fact, I feel Bunjil every time I come up to Camp Jungai. This is a very spiritual place. ${ }^{21}$

20 Roy Patterson, in conversation with Jennifer Jones, 3 March 2016, DS3001139.

21 Roy Patterson, in conversation with Jennifer Jones, 29 April 2016, DS300148-53. 
Camp Jungai is an ancestral ceremonial site that has been an outdoor education camp since the 1970s. It remains an important place of refuge, cultural maintenance and recuperation. Several of our bush tucker journeys started or ended at Camp Jungai, as important plant specimens are nurtured there by Taungurung people and camp employees. Providing non-Indigenous people with access to cultural education at Camp Jungai also enables custodians to foster respect:

Respect for our culture, respect for bush tucker, bush medicine and the spirit world. The Dreaming starts at birth and when you start to walk around, you start to learn. It goes through your whole life. The children are always watchin', and this is how they learn. ${ }^{22}$

Below is Uncle Roy's account of Taungurung culture as he understood it. Uncle Roy wanted to record, preserve and promote this generational knowledge. He makes plain that access to foods and medicines, and their preparation and sharing was determined by customary law and made safe by generational supervision. Readers are advised to exercise caution and asked to show respect for Taungurung intellectual property when engaging with natural resources.

\section{Blackwood wattle (Acacia melanoxylon)}

I'm going to give you some leaves and we will find some water, and you are going make soap. It is marvellous. What you do is take the leaves and make a ball out of it. Put your hands under water to wet them and then rub together hard and fast until the suds come. It has its own perfume and is your skin moisturiser and healing substance for dermatitis. Grab the leaves and rub them together in water and it will make soap. The leaves of the blackwood wattle or the inner bark of the blackwood wattle. All you do is put both your hands in the water with the leaves and pull them out and rub hard and fast and it will go frothy. If you rub long enough, it will take the dye out of the leaves and the soap will go free. You can smell the perfume in it and your hands are so soft, it is unreal; absolutely beautiful. The trouble is that they have all been cut down around here.

22 Roy Patterson, in conversation with Jennifer Jones, 3 March 2016, DS3001138. 
6. 'KNOWLEDGE COST YA NOTHING AND IS NOT HEAVY TO CARRY AROUND'

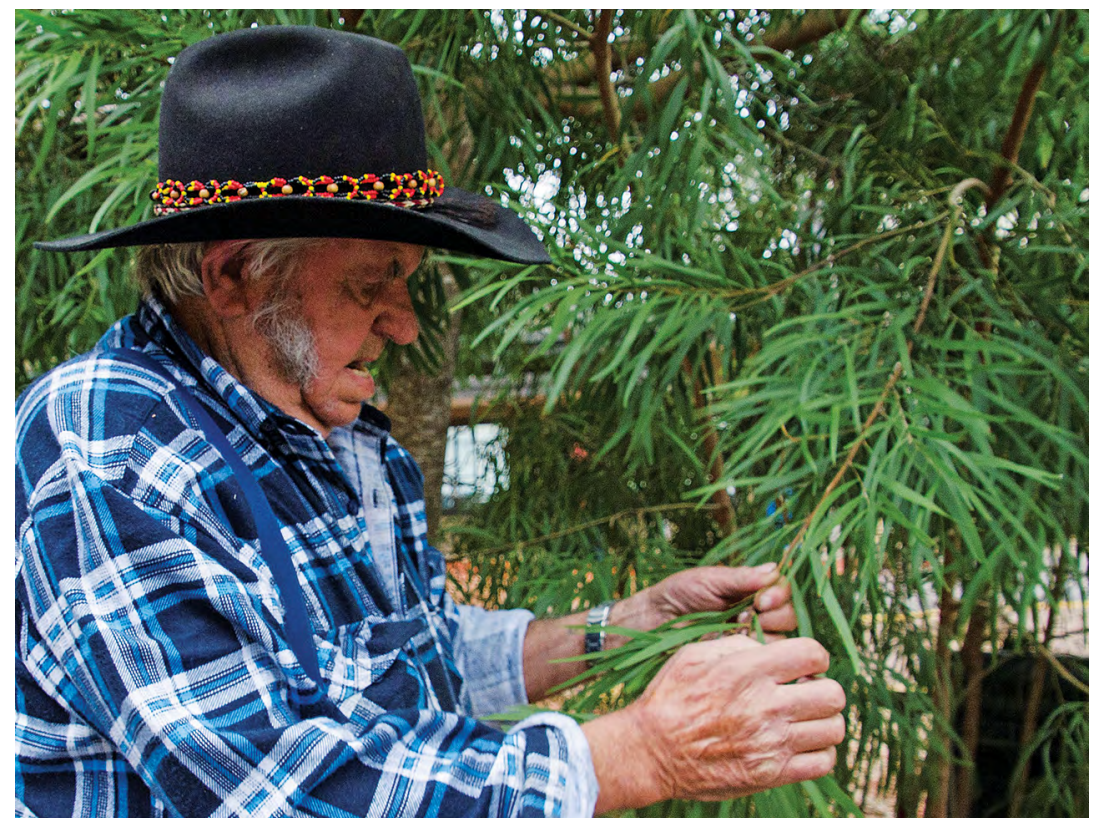

\section{Blackwood wattle}

Source: Photographed by Moorina Bonini.

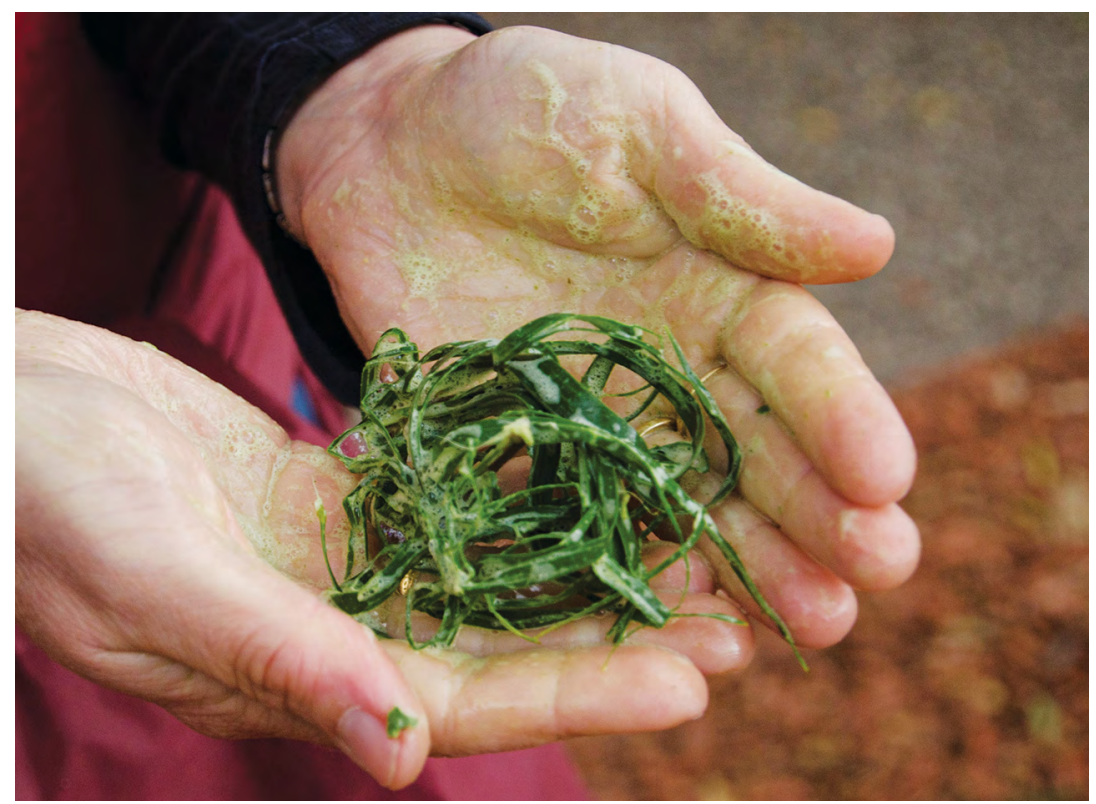

\section{Blackwood wattle soap}

Source: Photographed by Moorina Bonini. 
Well, you can also take the seeds out of the seedpods and grind them down to make a flour. You can use it in damper, scones and cakes, or make a drink out of it and it tastes very similar to coffee. You can use the seed in ice cream or mix it with your food for extra flavouring. ${ }^{23}$

\section{Bogong moths}

Cathedral here has the Bogong moth, oh yeah, in the spring, September-October, the ground is covered with them! Up at Camp Jungai, the kids say, 'Uncle Roy, what are these things?' I say, 'They are moths, you can eat them!', 'Urgh!' they say. Aboriginal people cooked them. They put a small stick through the moth, hold it over the fire for a few minutes, then pull him out and eat him; tastes a little bit nutty. They used to cook 'em up and when they went walkabout they had them in a bag and ate 'em cold and kept on walkin'. They never went hungry. ${ }^{24}$

\section{Bottle brush}

With the bottle brush, you grab the plant between the thumb and forefinger, and lick the honey off the flower, or you put it in your mouth and suck it off. They got natural honey in them. Every time you see a bird or a bee going to a bottle brush, you can take the honey off it too. ${ }^{25}$

\section{Bracken fern (Pteridium esculentum)}

While the bracken fern is little on the end you can eat them; just pick them off. They are light and tender and have a nutty taste, beautiful.

These are food plants, but the bracken fern is also good for bull ant and jump jack bites as well; they are mean nasty ones when they sting ya! Just rub it straight on the sting and within seconds it goes away.

23 Roy Patterson, in conversation with Jennifer Jones, 15 April 2016, DS300143.

24 Roy Patterson, in conversation with Jennifer Jones, 8-9 November 2016, DS300158-66

25 Roy Patterson, in conversation with Jennifer Jones, 29 May 2016, DS300148-53. 


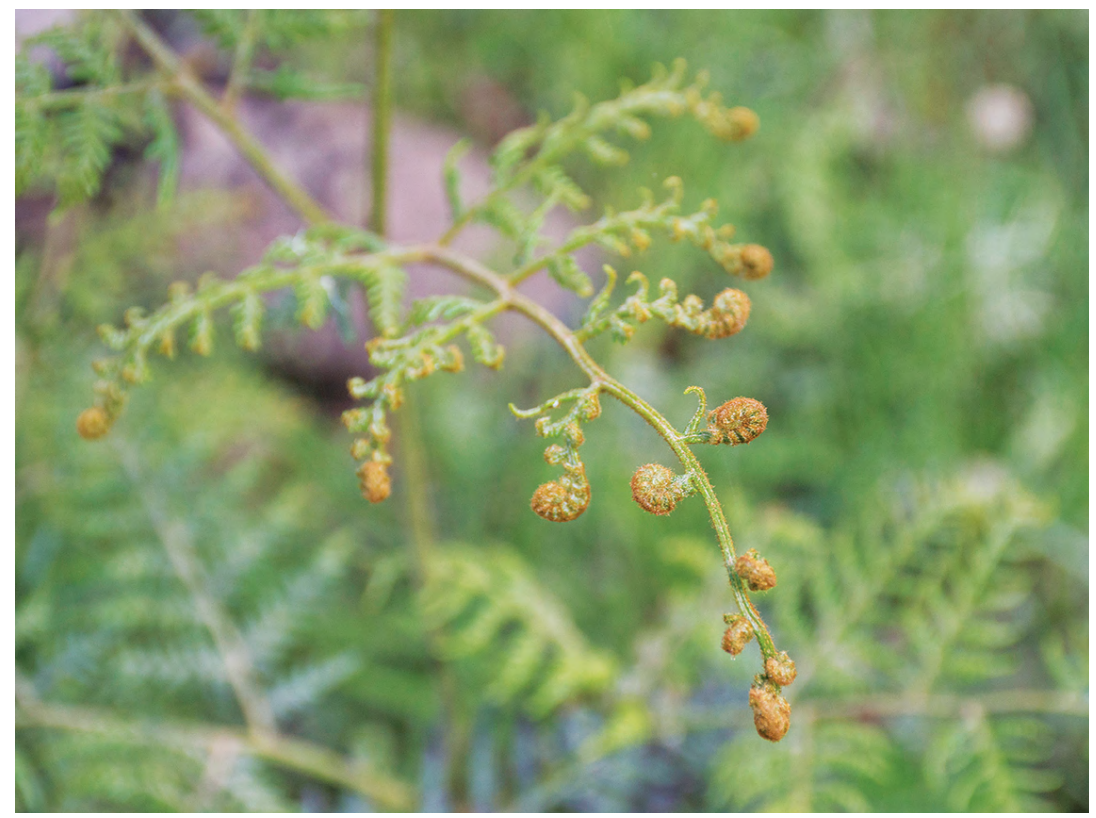

\section{Bracken fern}

Source: Photographed by Moorina Bonini.

My grandfather taught me about the bracken fern; put it in the water and wait for the fish to come to the top because it takes the oxygen out of the water and they come up to the top for the oxygen and 'bang, thank you' you've got them. You never took nothing that you didn't need. ${ }^{26}$

\section{Burr}

See this burr; if you get diarrhoea or gastro, you wash it and chew it and swallow the juice; chew and chew and chew until there is nothing left of the juice and then throw it out. Within 24 hours, your diarrhoea or gastro will be cured. Look how it grows here, I've got it everywhere at home in Taggerty. ${ }^{27}$

26 Roy Patterson, in conversation with Jennifer Jones, 12 July 2016, DS300154-56.

27 Roy Patterson, in conversation with Jennifer Jones, 8-9 November 2016, DS300158-66. 


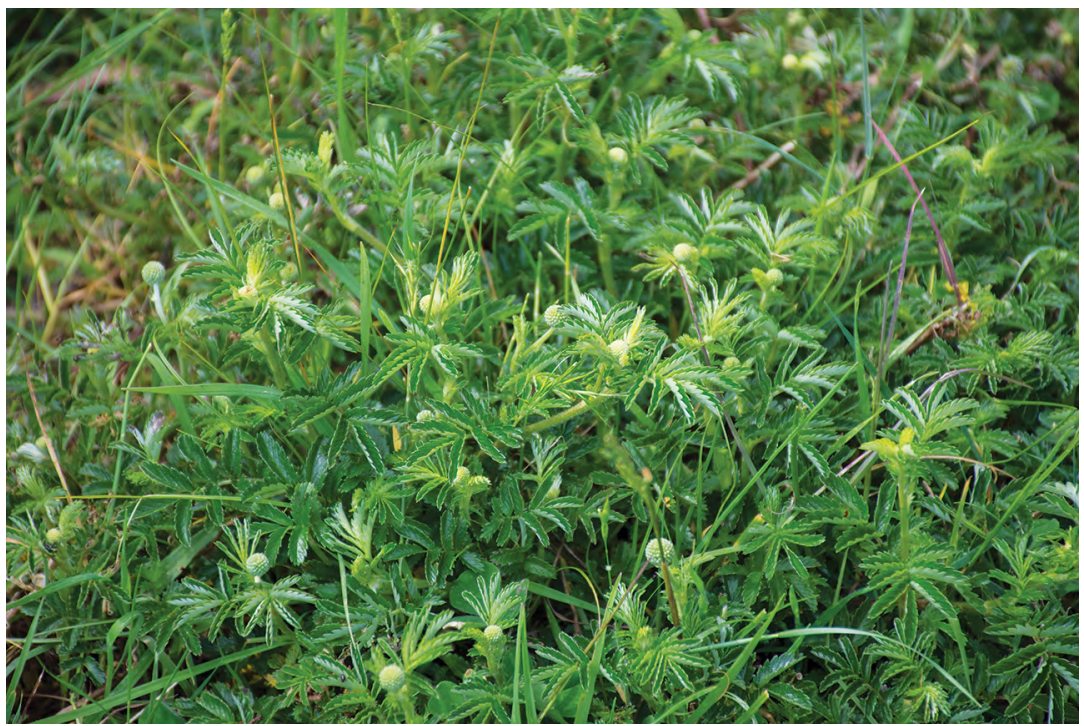

\section{Burr}

Source: Photographed by Moorina Bonini.

\section{Buxton gum (Eucalyptus crenulata)}

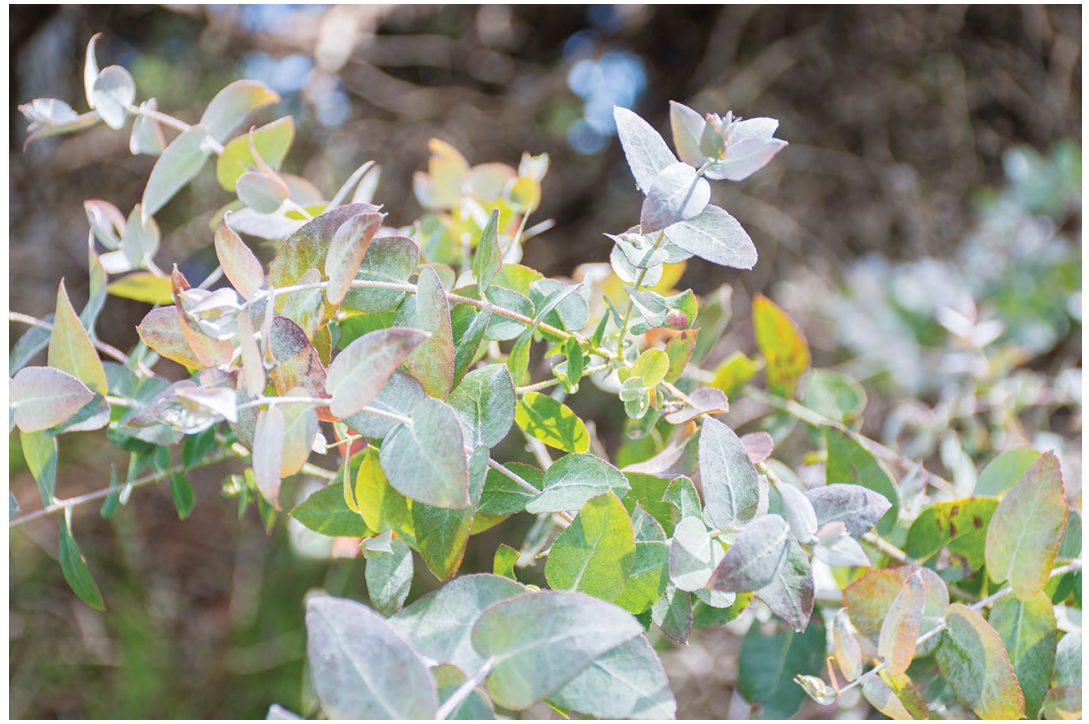

\section{Buxton gum}

Source: Photographed by Moorina Bonini. 
The Buxton gum is a rare and endangered tree found on the alluvial flats of the Acheron River near Buxton. It is a distinctive small tree of irregular form, growing to 12 metres high. The bark of the mature tree is rough over most of the lower trunk, but smooth on the upper trunk and branches. The leaves are blue-green in colour and retain distinctive juvenile-type foliage throughout its life. ${ }^{28}$ The leaf looks dry until you crush it, then it becomes shiny and sticky, releasing very strong fragrance:

The daughter of a friend of mine had whooping cough, and when she got rid of that, she got a chest infection. So, I got some Aboriginal medicine called Buxton gum. The Buxton gum is only grown in this area, and it's a medicine that my ancestors used. Europeans have been destroying that tree for years. To use it naturally you grate it up, wrap it in material, warm the material up and wrap it around your neck; not too tight, so the warmth of the material goes into your neck and the vapour of the Buxton gum goes up into your nose and all the way down into your lungs. This young Indigenous fella said to me the other day, 'that goes right through the bloody house Uncle Roy!' I said, 'that's good, take some more leaf home, keep on doin' it. If you are runnin' short, come up and git some more. This will heal ya'. I said, 'keep it up a week or two and it will cure whatever infection you've got in your throat'. Grab a leaf, screw it up, put it to you nose and breathe in deep. This is where you get the original Vicks VapoRub from! But Vicks VapoRub ain't as good as the natural thing. In the summertime, it is an insect repellent. It is a natural medicine; we've been using it 50,000 years; you get a bit tight in the chest and you rub the leaves between your hands and breathe it in.

Birds eat the seed and it won't dissolve in the bird's stomach. It comes out in the droppings and it grows stronger again and bigger and more beautiful. I've got this tree down at home, but it isn't as big as this one. I've been up here since 2002, and it was here then. The birds love it when the flowers come out, and so do the bees.

Buxton gum is also a good bloody repellent; gets rid of flies. All eucalyptus is good. I've just made up a new mixture for me arthritis; eucalyptus oil, tea-tree oil and emu oil. Mix them together

28 Department of Sustainability and Environment, 'Buxton Gum', accessed 28 November 2017, www. environment.vic.gov.au/_data/assets/pdf_file/0022/32584/Buxton_Gum_Eucalyptus_crenulata.pdf. 
and just rub it on and oh it is beautiful. So, we use everything we can. If you get a bit of a sprain, just get a eucalyptus leaf, twist it, break it and rub it on the sprain and what you are getting out of that leaf will start to ease the pain in that sprain. ${ }^{29}$

\section{White correa (Correa alba)}

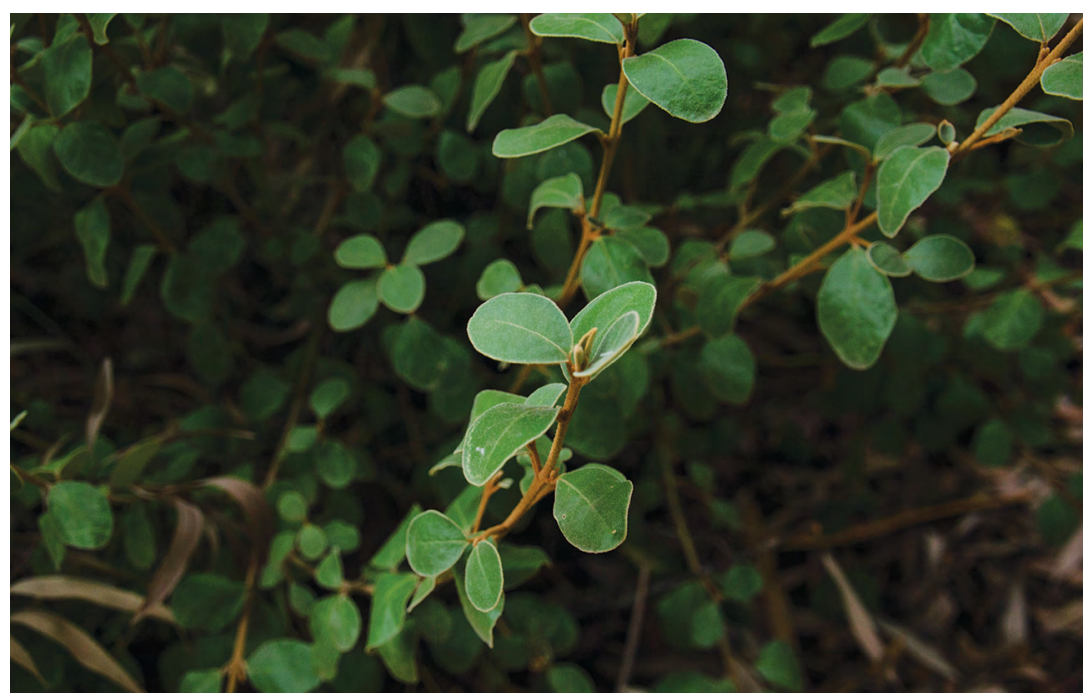

\section{White correa}

Source: Photographed by Moorina Bonini.

This is dense rounded shrub grows up to 1 metre in height and 2 metres in width. It has rounded grey-green leaves and bell-shaped white flowers:

The 'correa' has a little round leaf. You grab the leaves and as it is cooking the flavour goes right through the meat, the same as garlic does, but it tastes like a cross between basil and a bay leaf. You will want to take this plant home! It is absolutely beautiful. When my ancestors killed a kangaroo or an emu, they took the stomach out and put these branches in where the stomach was and while the meat is cooking the flavour is going through the meat. Earlier in the year, we put it in barramundi; with green leaves in it where the stomach was, and I put it on the BBQ in paperbark. Yum! It is one of our very special herbs. ${ }^{30}$

29 Roy Patterson, in conversation with Jennifer Jones, 15 April 2016, DS300143.

30 Roy Patterson, in conversation with Jennifer Jones, 29 April 2016, DS300145-47. 


\section{Cumbungi or bullrush (Typha latifolia)}

These are ones that are in the water and you go down and cut them off. You can eat the roots if you cook them. ${ }^{31}$

\section{Dogwood tree grub}

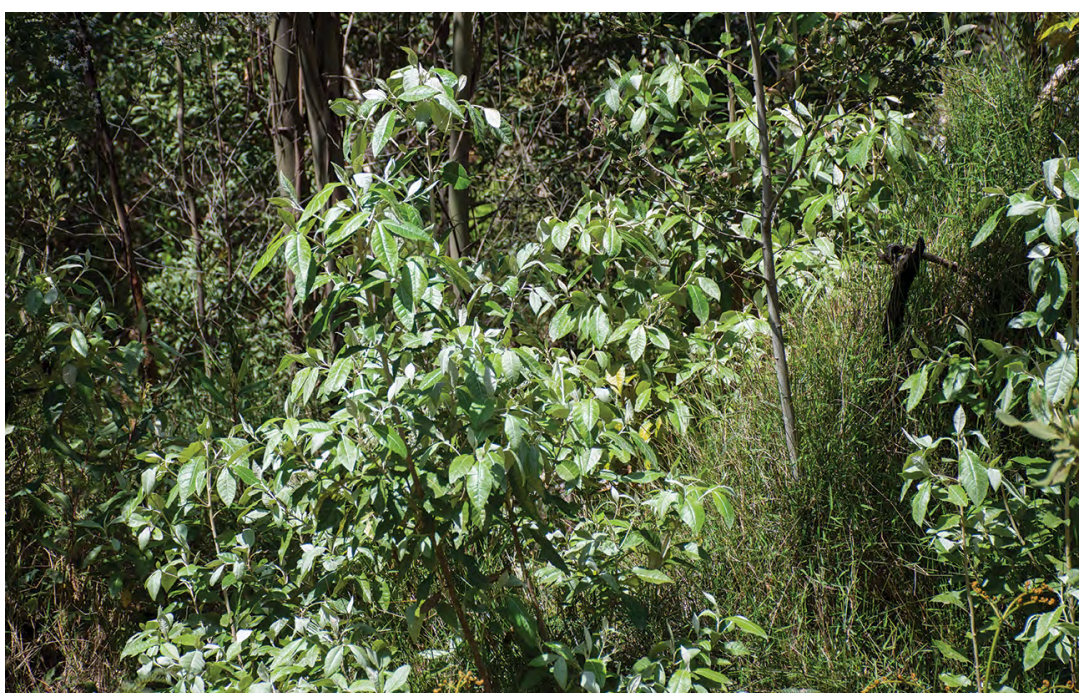

\section{Dogwood tree}

Source: Photographed by Moorina Bonini.

Non-Aboriginal attitudes to Australian edible grubs have been heavily influenced by culturally chauvinistic representations of Aboriginality. Edible grubs are larvae of moths that feed in the trunks of host plants. They provide a significant source of seasonal nutrition. ${ }^{32}$

The Dogwood grows beside mountain streams. The good thing about it is it gets a grub in it. When you look at the Dogwood, you see a little bit of sawdust where the grub has gone in. If it is a dark sawdust, it has been in there for a while. You break the spot open and the grub might be down further about 18 inches or 2 feet; grab it out and eat it. It tastes like peanut butter, I ain't jokin'. It happens in the spring, before all the moths come out. It only grows about

31 Roy Patterson, in conversation with Jennifer Jones, 29 April 2016, DS300148-53.

32 Yen et al., 'Current Issues'. 
2 inches long and about the thickness of a match. They are an orangey colour. I tell you, they make good fish bait too, the fish love'em, oh yeah, they are beautiful. ${ }^{33}$

\section{Egg and bacon plant (Eutaxia myrtifolia)}

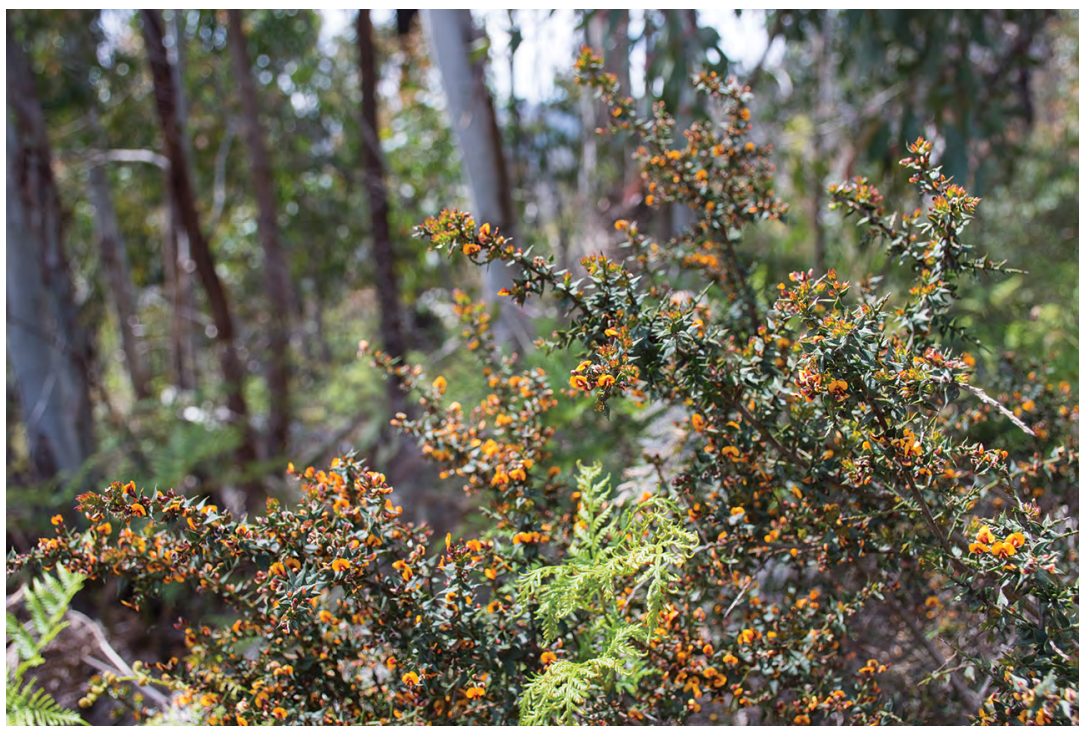

\section{Egg and bacon plant}

Source: Photographed by Moorina Bonini.

The egg and bacon plant; you boil up the flowers into a tea. You can drink it hot or cold and it's good for blood pressure: high or low. It's a medicine. It's a spring flowering plant. You put the branch and the leaves and all in, and it is already sweet. ${ }^{34}$

\section{Fire as a bush management tool}

We didn't burn the bush when it was bone dry. We burnt when there was dew on the ground; burn one section, then another section, then a section until they would burn into each other. We never let it get away from us. ${ }^{35}$

33 Roy Patterson, in conversation with Jennifer Jones, 8-9 November 2016, DS300158-66.

34 Roy Patterson, in conversation with Jennifer Jones, 8-9 November 2016, DS300158-66.

35 Roy Patterson, in conversation with Jennifer Jones, 12 July 2016, DS300154-56. 


\section{Fishing techniques}

We used to use nets made out of grasses. Then we'd find a nice very slow pool flowing off fast water; put a rock around it to hold the net up and get bracken fern and take the dirt off the roots and crush it up. The white stuff that comes off the bracken fern, you put that into the water; any fish in there can't breathe because it takes the oxygen out of the water; and we can pick them up. ${ }^{36}$

\section{Fish rib fern}

Fish rib fern tastes like almond. This will do the same thing for ant bites and mosquito bites. It is powdery, so it makes your mouth dry as well. You only eat the young shoots as a snack, not the old ones. The ones with the curl on the end are the best one to eat; nice and fresh. They call it fish rib fern because the seeds look like fish eggs. Everything around here is educational; bush tucker and medicine and special sites. ${ }^{37}$

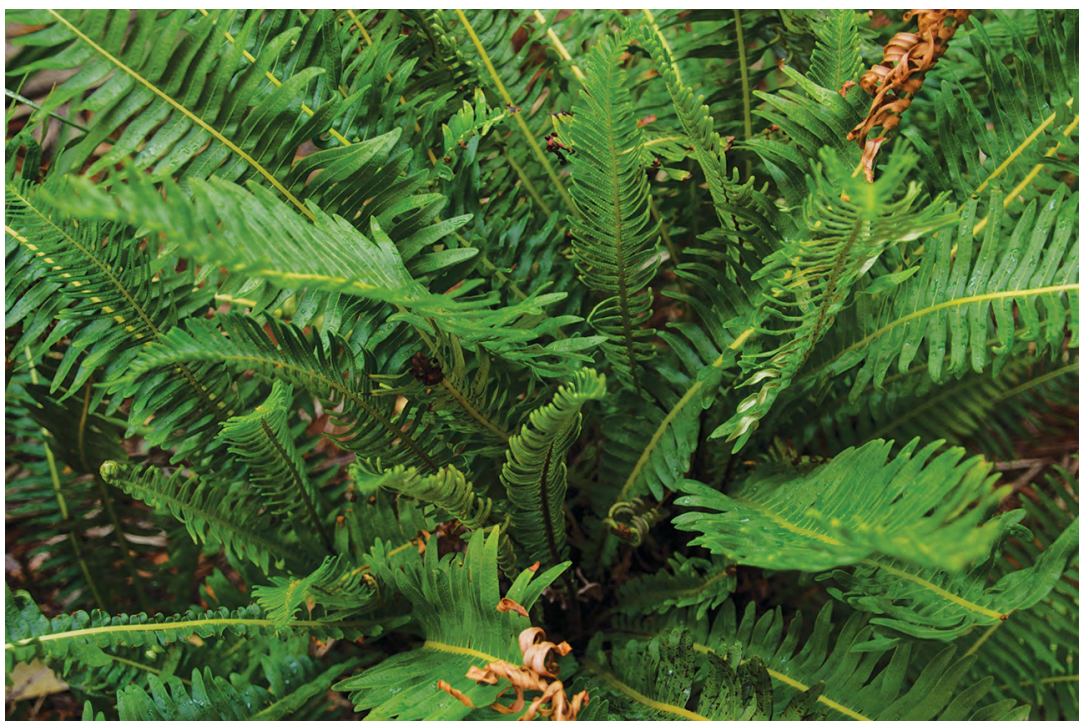

Fish rib fern

Source: Photographed by Moorina Bonini.

36 Roy Patterson, in conversation with Jennifer Jones, 12 July 2016, DS300154-56.

37 Roy Patterson, in conversation with Jennifer Jones, 29 April 2016, DS300145-47. 


\section{Kangaroo apple (Solanum aviculare)}

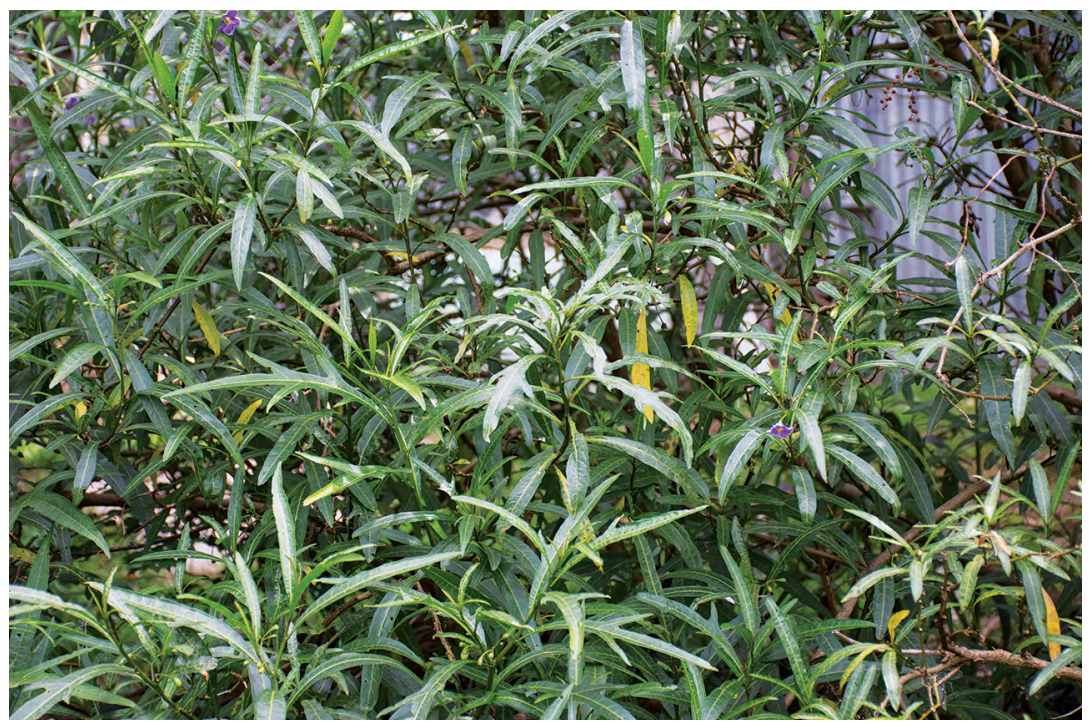

\section{Kangaroo apple}

Source: Photographed by Moorina Bonini.

This tall shrub with glossy dark green leaves is found in higher rainfall areas. It has a delicate purple flower and edible fruit that starts green and turns yellow to orange and red as it ripens.

The kangaroo apple plants here on Mount Cathedral has a purple flower that comes before the seed, when the perfume comes out. They are a relative of the deadly nightshade; one is black and the other is purple and they are deadly. But this is women's business, women's medicine, so I can't go any further. ${ }^{38}$

38 Roy Patterson, in conversation with Jennifer Jones, 8-9 November 2016, DS300158-66. 


\section{Lemon-scented tea-tree}

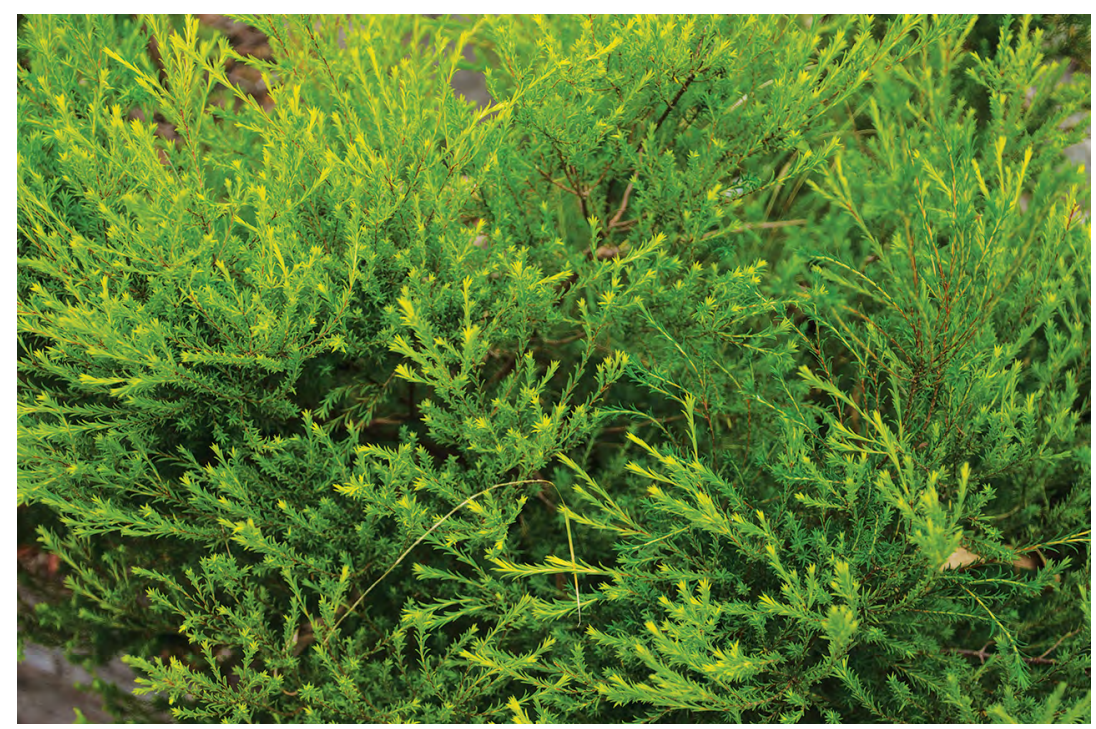

\section{Lemon-scented tea-tree}

Source: Photographed by Moorina Bonini.

This beautiful plant here is the lemon-scented tea-tree. Rub that in your fingers and smell it. I've got one growing at home. When you are making a cuppa tea, put it in your tea and it makes beautiful herbal tea. The same with the young leaves of the eucalyptus tree. You pick 5 centimetres of the lemon-scented tea-tree and put it in your water with some native mint, and it stops motion sickness. You put it in the water, shake it up and get the flavours in the water and drink the water. I give it to the kids when they go home from Camp Jungai in the bus. When they get back to school the teachers thank me, because no one was sick on the bus! Otherwise, as they are going home they are spewing everywhere. I've got a son who even now cannot sit in the back seat, but he can sit in the back seat with a bottle with this stuff in it, and it will stop the squirmy tummy. ${ }^{39}$

39 Roy Patterson, in conversation with Jennifer Jones, 29 April 2016, DS300145-47. 


\section{Moss}

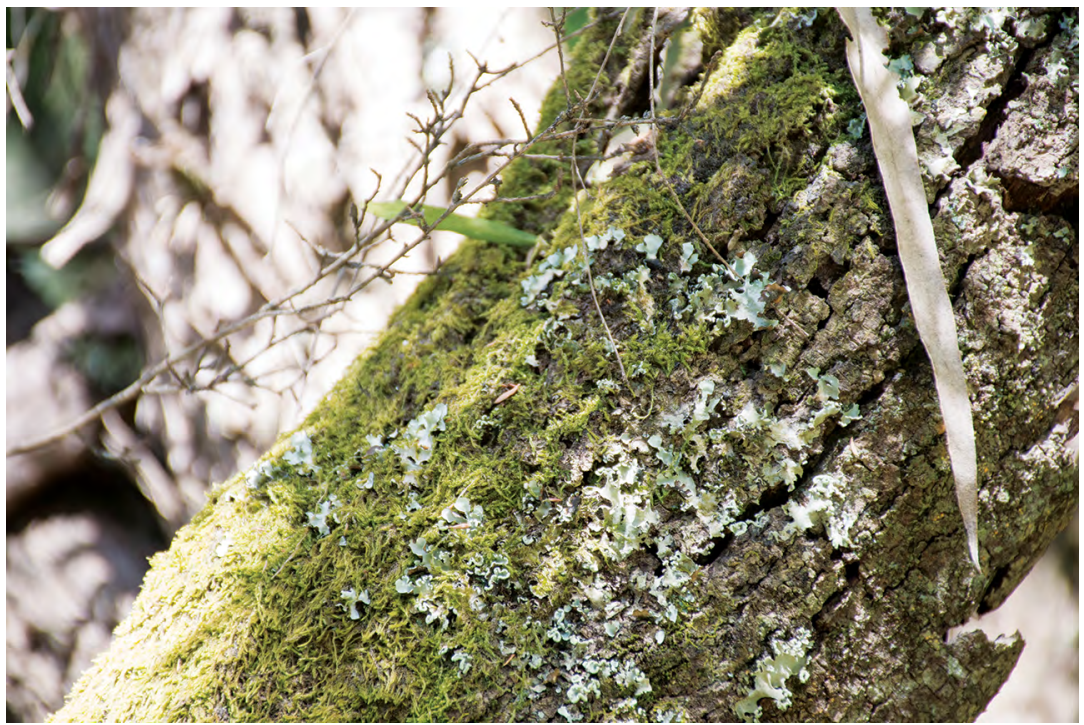

Moss

Source: Photographed by Moorina Bonini.

Moss is the greatest antiseptic you can ever get for cuts and burns. If they've got a fresh cut or burn, you sit it moss-side down on the wound and, if you have a bandage, wrap it around. You can get some of that rib grass and wrap it around to hold it on. ${ }^{40}$

\section{Mountain pepper (Tasmannia lanceolata)}

Mountain pepper is a tall evergreen shrub or small tree of up to 10 metres high that prefers the cool wet habitats of high mountain gullies and the slopes of tall open forests. There are separate male and female plants. The trunk is straight, with distinctive reddish branchlets and leathery leaves that have an unusual fragrant, spicy flavour. Mountain pepper fruit is berry-like, about 5-8 millimetres in diameter, shiny, dark red, turning black when ripe. Initially they have aromatic, mildly spicy flavour, then, after a short delay, a more intense pepper taste. ${ }^{41}$ Uncle Roy loved sharing his mountain pepper harvest:

40 Roy Patterson, in conversation with Jennifer Jones, 8-9 November 2016, DS300158-66.

41 Royal Botanic Gardens Victoria, 'Tasmannia lanceolata, Mountain Pepper', accessed 24 April 2020, vicflora.rbg.vic.gov.au/flora/taxon/5505a156-251b-4f32-8711-f4e08c2ab9c2. 
I can't get enough of mountain pepper. Every time I get it, I lose it, because people say, 'Oh, Uncle Roy, you got any more of that black pepper?' Two years ago, I got five ice cream containers full of those berries, and within a week I never had any left. My nextdoor neighbour, his daughter, daughter-in-law, staff at Camp Jungai and Holmesglen TAFE College- 'Oh, I've got none left'. The leaf is just as good. It is very easy to pick, there are no thorns; they grow up in the Toolangi area. The native mountain pepper is a berry. You dry it out [in the oven] and grind it down and you've got a beautiful pepper. Get the leaf, and you can eat it raw; put it in a salad, put it in your stews or into your roast, and the flavour goes into the food. You bite and chew the leaf, and it is just like eatin' a little bird's-eye chilli, maybe not so hot, but it is warm! You pick the berry no later than the second week of March; they are also on the back of Mount Monda in the Narbethong Yarra Ranges National Park. ${ }^{42}$

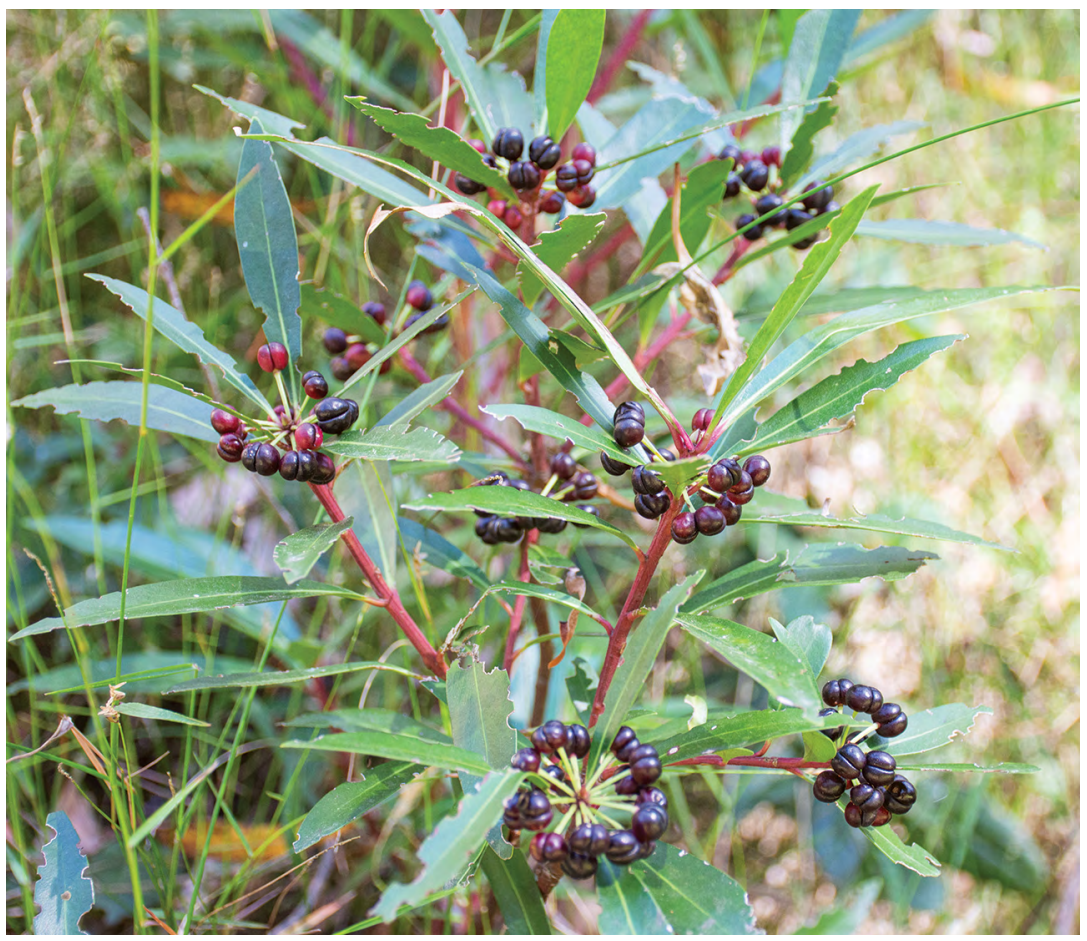

Mountain pepper

Source: Photographed by Moorina Bonini.

42 Roy Patterson, in conversation with Jennifer Jones, 15 April 2016, DS300143. 


\section{Milk thistle}

If you have got a wart, break the milk thistle off and when the milk comes out, spread it over and let it dry and you'll get rid of the wart. They have a white flower when they open.

\section{'Native Bread’ (Polyporus mylittae)}

The staple diets of Taungurung people were severely disrupted once land clearance and cultivation intensified in the Taggerty district. Marion Arminell Burchall was a four-year-old child when her parents selected densely timbered land for clearance and farming near Taggerty in 1876. In her memoir, she recalled that Aboriginal clans periodically returned to the Upper Goulburn River district from Coranderrk, camping near their family farm on their way to Thornton:

We used to go over to the camps on our way home from school. When they camped they always built Mia Mia’s. They used to dig up yams out of the ground to eat [and] native bread (a big white fungus). Sometimes my father used to find big lumps of native bread when he was ploughing and he used to make it into round balls for us to play with. ${ }^{43}$

Uncle Roy recalled:

There was a yellow fungi that grows above ground and down below it in the ground the fungi grows in a big ball; up to 20 kilos. That used to be our bread; get a fire going, cook it and eat it. You couldn't eat it without being cooked. The fungi up top, the mushroom, it's got all the seeds, so you leave that there where you found it. ${ }^{44}$

43 'Some True Stories about the Aborigines of Victoria for Vivienne Hulley and Audrey Bevan, Read by Mrs Marion Popple of Wymarong', Aborigines of Australia-Miscellaneous Reminiscences, Royal Historical Society of Victoria, MS 22545, Box 118/11.

44 Roy Patterson, in conversation with Jennifer Jones, 12 July 2016, DS300154-56. 


\section{Native cherry (Exocarpus cupressiformis)}

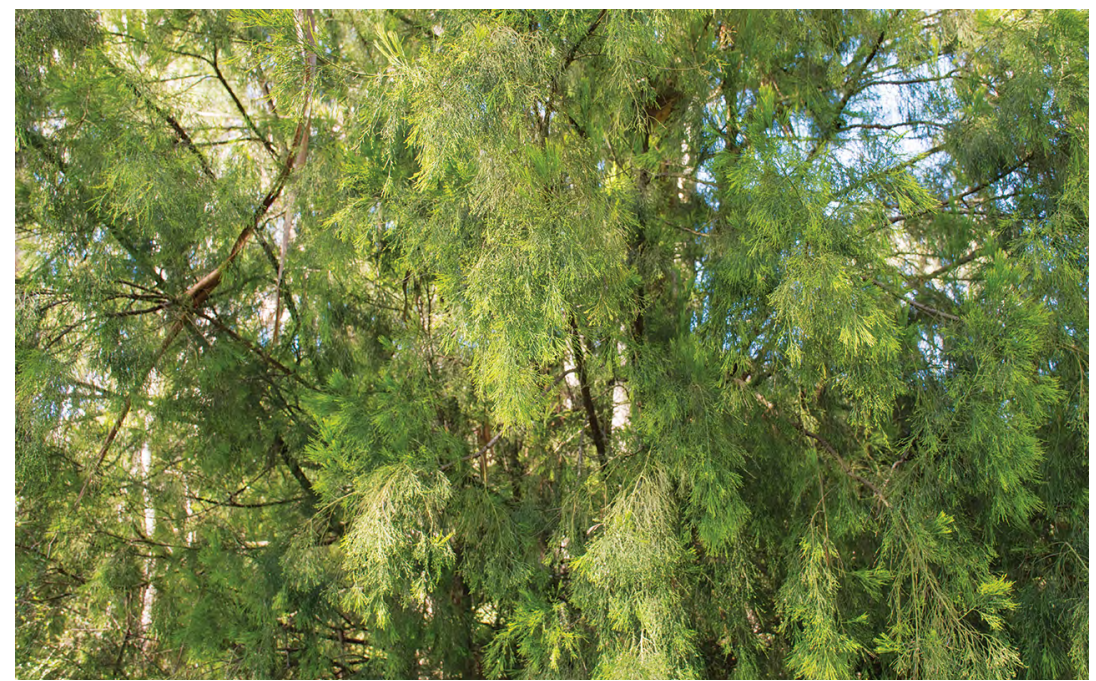

\section{Native cherry}

Source: Photographed by Moorina Bonini.

This small tree has the appearance of a conifer, with yellow-green weeping foliage and growing 3-8 metres high. Small cream flowers are followed by the fruit: a small, hard fruit supported on a larger, swollen and fleshy stalk that turns red, becoming sweet and palatable. ${ }^{45}$ The wood from the native cherry was used for spearthrowers and bullroarers, and the sap for snakebite:

The native cherry comes out in November too, but you've got to be quick to beat the birds to it. We used them for Christmas trees because of the red berry on them. They start off as a green berry about the size of your fingernail, then orange, then red; when they are red they are absolutely beautiful. They get about 1 centimetre or a bit bigger. The green part on the back is the seed; you eat the red part and throw the green part away. Awh, you won't leave them alone neither, once you start eatin' them. They going to be loaded this year, thanks to the good spring rain. I came up here to Camp Jungai one day with a group, and the tree was loaded. After the session, it was morning teatime and you couldn't see a student anywhere! They were all down there getting into the cherries! ${ }^{46}$

45 Royal Botanic Gardens Victoria, 'Exocarpos cupressiformis, Cherry Ballart', accessed 24 April 2020, vicflora.rbg.vic.gov.au/flora/taxon/10a16917-01e0-46cc-8bd8-359df2467806.

46 Roy Patterson, in conversation with Jennifer Jones, 29 April 2016, DS300148-53. 


\section{Native mint (Mentha australis)}

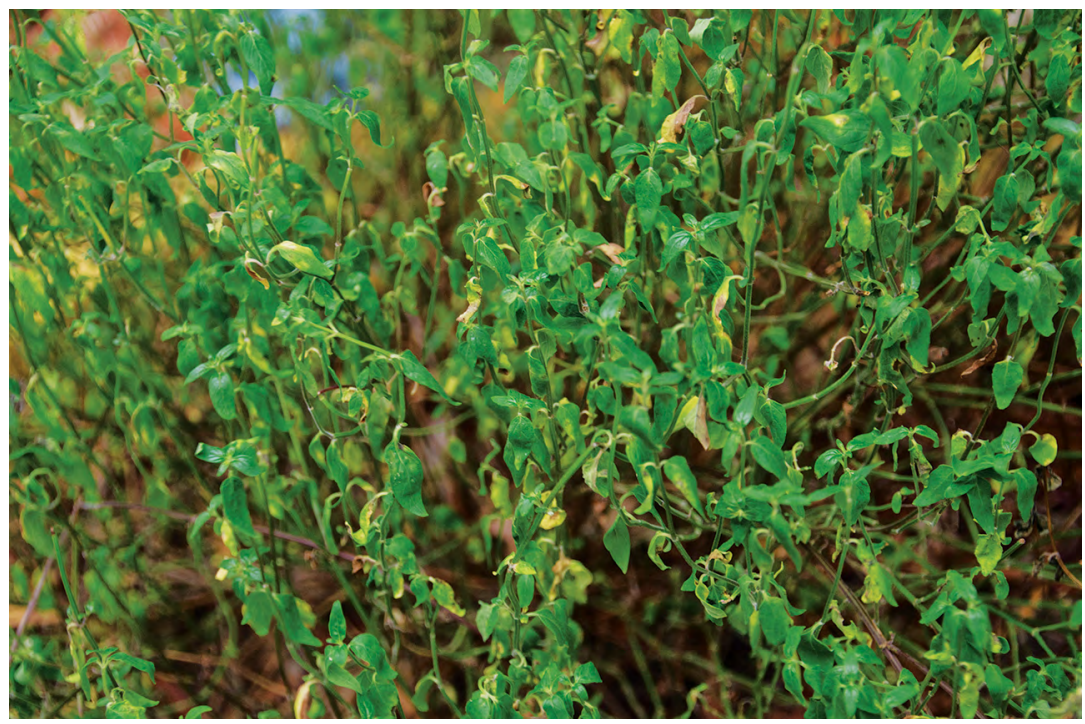

\section{Native mint}

Source: Photographed by Moorina Bonini.

Pick a leaf off that and eat it. You can tell the difference between native mint and European mint because the stem of the native mint is square, while European mint is round. It only grows in this area, there are five different types. The ones here include:

- Natural peppermint: It isn't as strong as the mint. It has the same square stem but a softer taste.

- Native river mint: It is coming out of the ground here because it's been recently flooded. It had a purple edge as a young plant, when it first comes out, then it goes green. You can eat that now; it's strong and beautiful in a cup of tea. It grows about 50 centimetres high. They die off in the summertime and come back in the wintertime. This is the native mint to mix in with your water for motion sickness. ${ }^{47}$

47 Roy Patterson, in conversation with Jennifer Jones, 29 April 2016, DS300145-47. 


\section{Native raspberry (Rubus parvifolius)}

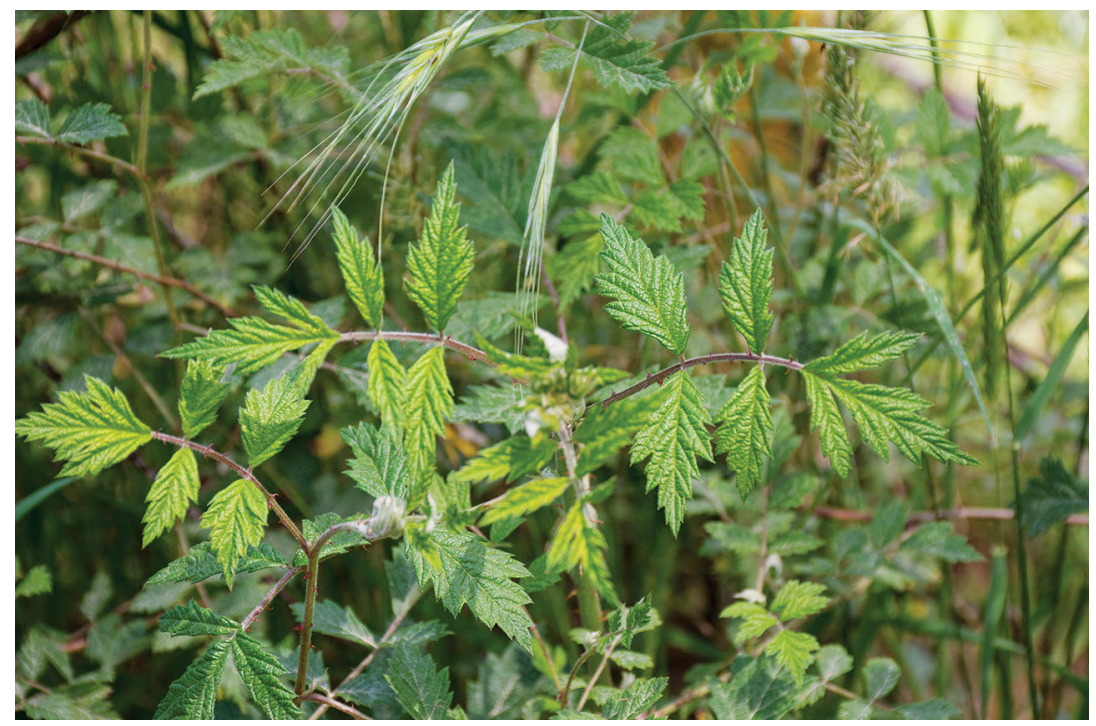

\section{Native raspberry}

Source: Photographed by Moorina Bonini.

This scrambling, prickly shrub or bramble has small bright green, wrinkled leaves and small, delicious fruit. Growing in mountain gullies, the native raspberry has often been displaced by the introduced blackberry, also a Rubus species: ${ }^{48}$

The native raspberry: it looks a bit like a blackberry bush, but the leaves stay small. White people call them blackberries, but they have a smaller leaf and smaller berry and they are sweeter. The berries make better jam than blackberries. My mother, when we were kids, 'all you buggers, go and get me some raspberries'. We'd come back with a couple of bucketful's and mum would make native raspberry jam, ahh! It's better than blackberry and I love blackberry I can tell ya. But they spray them all with poison thinking that they are blackberries and kill them. They are very similar, they start off green, go red, and then black, but a smaller berry. They are beautiful. ${ }^{49}$

48 Royal Botanic Gardens Victoria, 'Rubus parvifolius, Small Leaf Bramble', viewed 24 April 2020, vicflora.rbg.vic.gov.au/flora/taxon/bc19413d-6b07-4c94-84ee-4b5fef7e2f98.

49 Roy Patterson, in conversation with Jennifer Jones, 3 March 2016, DS3001139. 


\section{Orchids $^{50}$}

With the orchid, you dig the bulbs out, but leave the flower there because the seed's in the flower. If you pick the flower and take it, you destroy the plant. There aren't many orchids around here now; I was down at Mitcham down near Nunawading, and this bloke was an expert on the orchid. He said that he used to come up here and get all the orchids. That is why they started to disappear. He didn't realise that he was taking the seed away. I wasn't very pleasant to him! I said to him, 'the big bulbs on the bottom; that's your tucker, not the seed'. Not only him, people would be driving along the road and would see a beautiful flower and say, 'we'll pick that', and they take the seed away. We lose a lot of our stuff because of that. ${ }^{51}$

\section{Prickly currant (Coprosma quadrifida)}

This prickly plant is an erect, open to dense shrub with fine spines on its branches. It has sweet edible red fruit from January to March: ${ }^{52}$

The prickly currant is real bushy, just snip the dead branches off and let it grow in the winter. It starts off green and when it turns red, you can eat it, and eat it, and eat it! You won't stop eating it! The kids all know about it. Awh, they are beautiful eating. The fruit comes all along the stem here and they are absolutely gorgeous. Once you start, you can't stop. You just grab them and eat them. It is indigenous to here, all along the river you will see it. There is another prickly current, they are all along here. This is why we never went hungry. Can you blame us for going crook when white people took all our bush tucker away and our bush medicine? The majority of what you eat is also medicine. ${ }^{53}$

50 For a list of threatened orchids of the district, see Statewide Integrated Flora and Fauna Teams, 'Threatened Flora Yarra Ranges Shire', viewed 11 May 2020, www.swifft.net.au/cb_pages/threatened_ flora_yarra_ranges_shire.php.

51 Roy Patterson, in conversation with Jennifer Jones, 12 July 2016, DS300154-56.

52 Royal Botanic Gardens Victoria, 'Coprosma quadrifida, Prickly Currant', accessed 24 April 2020, vicflora.rbg.vic.gov.au/flora/taxon/1b8f3911-2ea5-499d-88af-ffe7fc4dbdb4.

53 Roy Patterson, in conversation with Jennifer Jones, 29 April 2016, DS300148-53. 


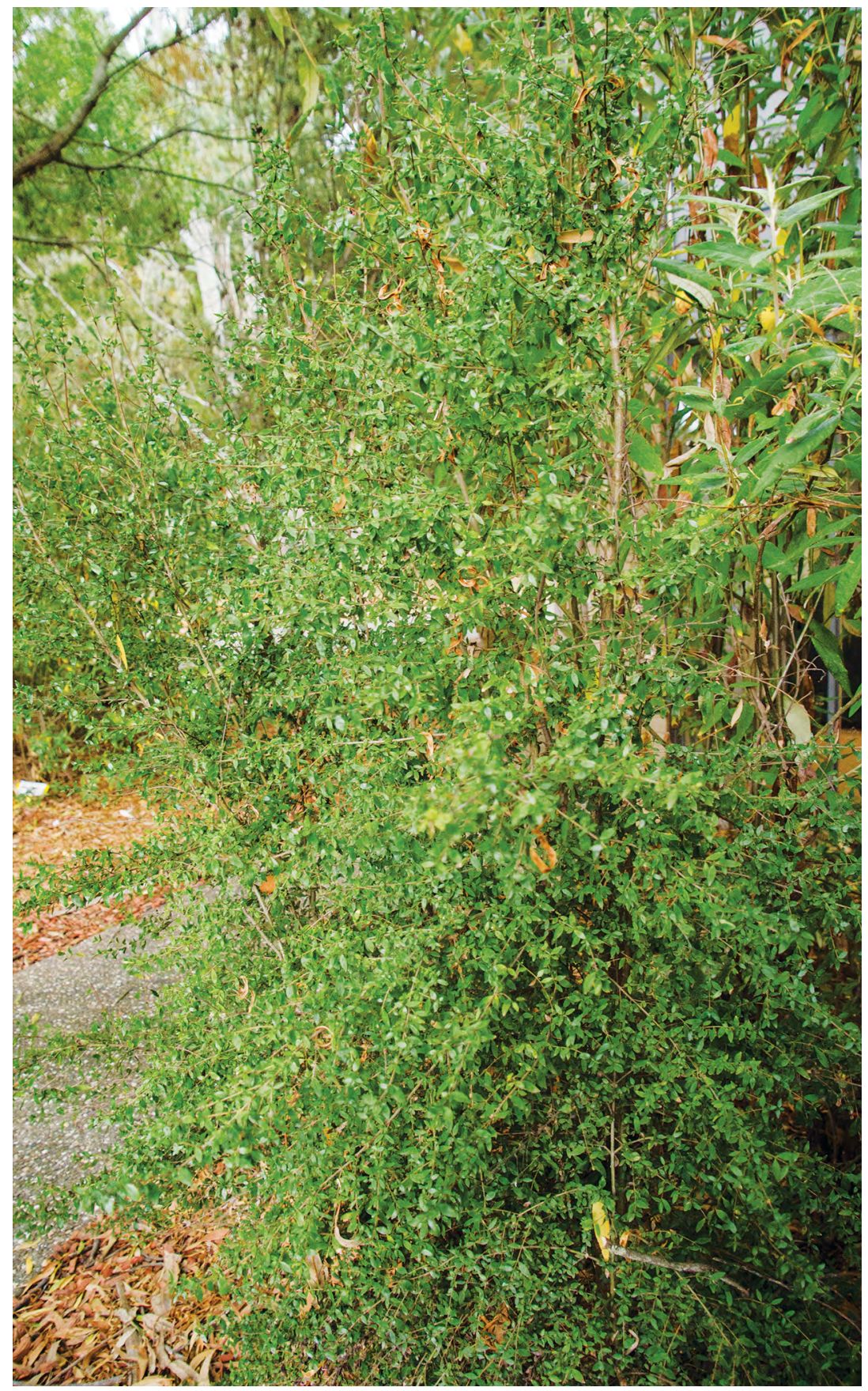

\section{Prickly currant}

Source: Photographed by Moorina Bonini. 


\section{Rib grass}

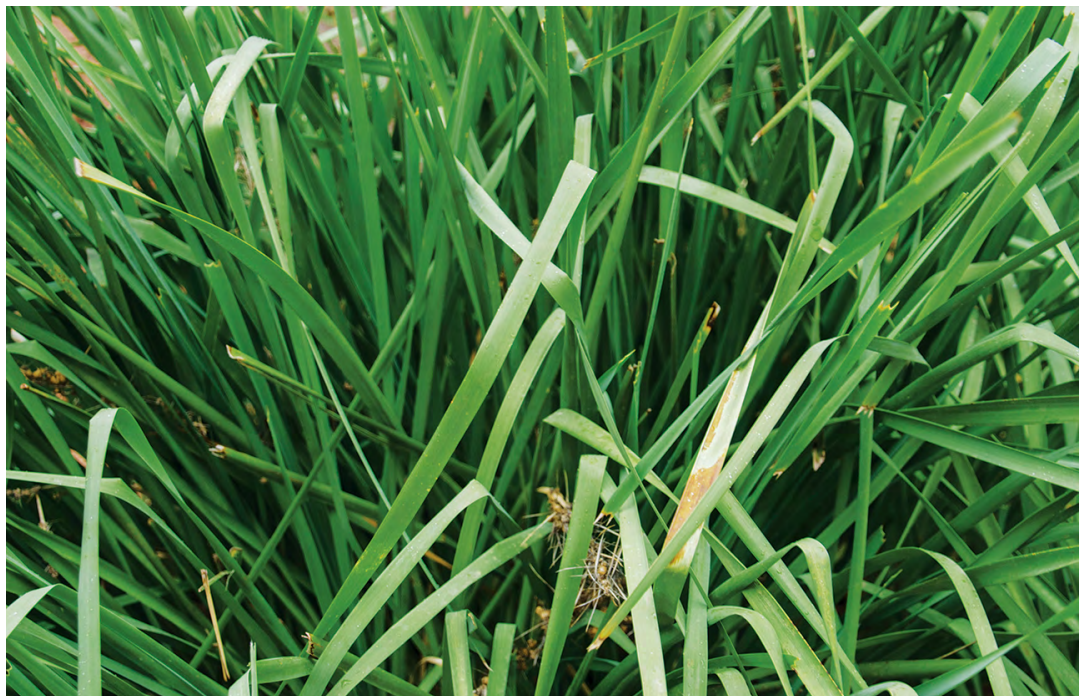

Rib grass

Source: Photographed by Moorina Bonini.

With this one, you eat the white bit; it tastes a bit like snow pea. You can grow this at home and put the white part in your salad. The white bit is the medicine. If you cut yourself or burn yourself, wind the rib grass around it tight, and two or three hours later you can take it off and you won't see where you have burnt yourself and the cut will heal from the inside out, not the outside in. A young bloke I know had a bad burn on his hand. He said, 'what am I going to do with this Uncle?' Got a few plants here, ribbon grass, cut the white part of it and stuck it on, put another one around it, and another one for about three hours. A young woman come to see what I was doing, and she had a big cut on her leg, 'what am I going to do with this Uncle?' Same thing, for two or three hours. After that, take it off and you couldn't even see the burn or the cut. They said, is this Blackfella medicine? I said 'yeah', and they couldn't thank me enough. I said, 'it's also tucker', and they said, 'what do you mean?', and I gave one to each one of them and said, 'eat the white bit and tell me what it tastes like', so they tasted it, 'it tastes like a snow pea'. They were right on the bloody knocker. It grows into a big bush, but up there they are rippin' it out, left, right and centre. People who don't know what they are doing try to get rid of them, but they still grow again, and it is beautiful. 
Now with this one, when you twist it, it makes it stronger. Put the white bit in your mouth and then plait the strands. You can do weaving with these as well, basket weaving. ${ }^{54}$

\section{River blackfish (Gadopsis marmoratu)}

Up here, we've got 'slimies', which is a river blackfish; you go to pick them up and they slip out of your hand. We used to use nets, made out of grasses. Then we'd find a nice very slow pool flowing off fast water; put a rock around it to hold the net up, get bracken fern and take the dirt off the roots and crush it up. The white stuff that comes off the bracken fern, you put that into the water; any fish in there can't breathe because it takes the oxygen out of the water; and we can pick them up. ${ }^{55}$

\section{River red gum}

This is the flowering river red gum. These young eucalyptus leaves, take the bright green, small young tips off the end of it and put it in your tea, and you get a eucalyptus flavour and it is beautiful. Now, the flowers form nuts when the flowers drop off. Our ancestor women used to make necklaces and that out of them. Before that, they've got sweet nectar in them, natural pure honey. You ought to see the bees go for it: bush lollies, ooh yeah! You watch the birds and the bees get honey, and you can eat it.

This is only a very young tree; it will grow into a big one. Rub these leaves together in the palm of your hand and then smell them; strong eucalyptus opens up the airway into your lungs. It's absolutely beautiful. You smell it like that and it clears the airway right into your lungs. ${ }^{56}$

Early colonist Dr W.H. Baylie recorded the pleasure of watching Aboriginal mothers teaching their babies, barely yet able to crawl, to find the sweet sap of the gum. In 1843 he wrote: 'she provides [the infant] with a gum stick and teaches the little thing to search for exudation [gum or sap] upon it, which they esteem so as a great luxury in their repasts'. ${ }^{57}$

54 Roy Patterson, in conversation with Jennifer Jones, 3 March 2016, DS3001139.

55 Roy Patterson, in conversation with Jennifer Jones, 12 July 2016, DS300154-56.

56 Roy Patterson, in conversation with Jennifer Jones, 8-9 November 2016, DS300158-66.

57 Baylie, 'On the Aborigines of the Goulburn District', 135. 


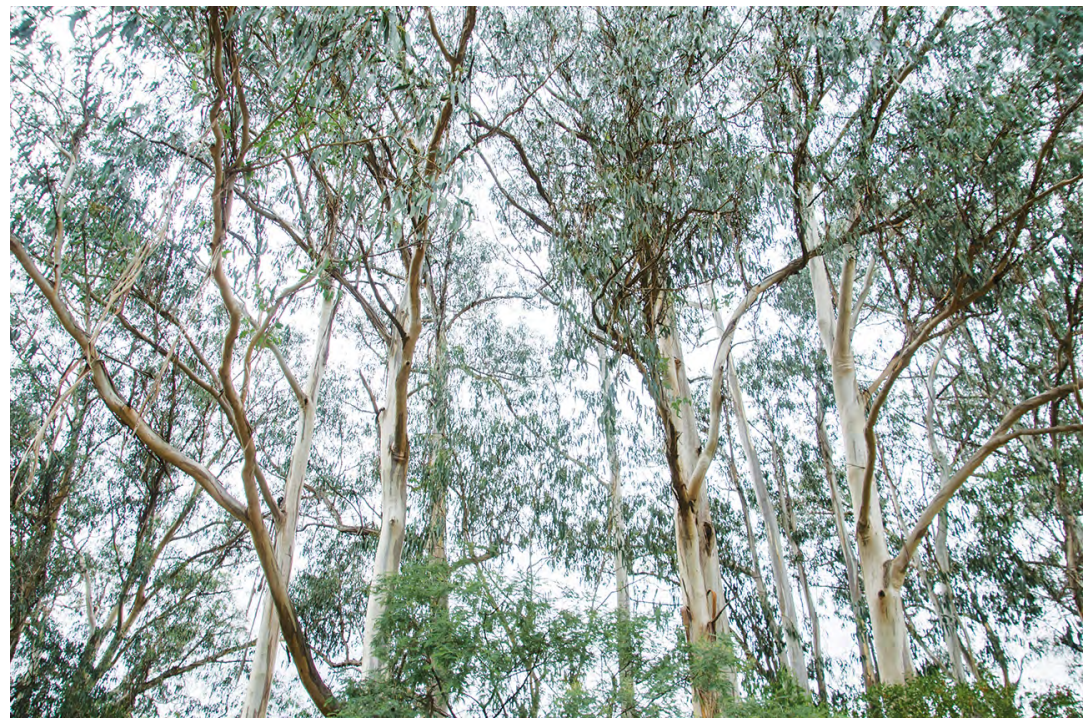

\section{River red gum}

Source: Photographed by Moorina Bonini.

\section{Scar trees}

See that scar on that river red gum, that is a coolamon scar. They took the bark for a coolamon, which is a carrying basket, but they didn't do it properly and the tree has grown bark back over to protect itself. It should have been on the shady side away from the north sun, then the bark wouldn't have to grow over the top. See this? This old scar: that is the shape of a canoe to go on the river. The bark was taken off this tree many, many years ago. There is another one down there. They were in the shade and protected, so it doesn't matter if it is on the north-east side, because it has got good shade. That one down there is a modern-day one. What you do is, you've got to cut around the shape that you want it. Then you get a stick, like a small sapling, you slowly put it in behind the bark, so you don't crack it and break it. It can take you 10-12 days to get that off the tree. You keep sliding the wood up and down it; what you are doing is breaking the sapwood and slowly lifting the bark off the wood. The bark is about $25-30$ centimetres thick. They might have only used it to cross the river, and then come back again. ${ }^{58}$

58 Roy Patterson, in conversation with Jennifer Jones, 9 November 2016, DS300158-66. 
6. 'KNOWLEDGE COST YA NOTHING AND IS NOT HEAVY TO CARRY AROUND'

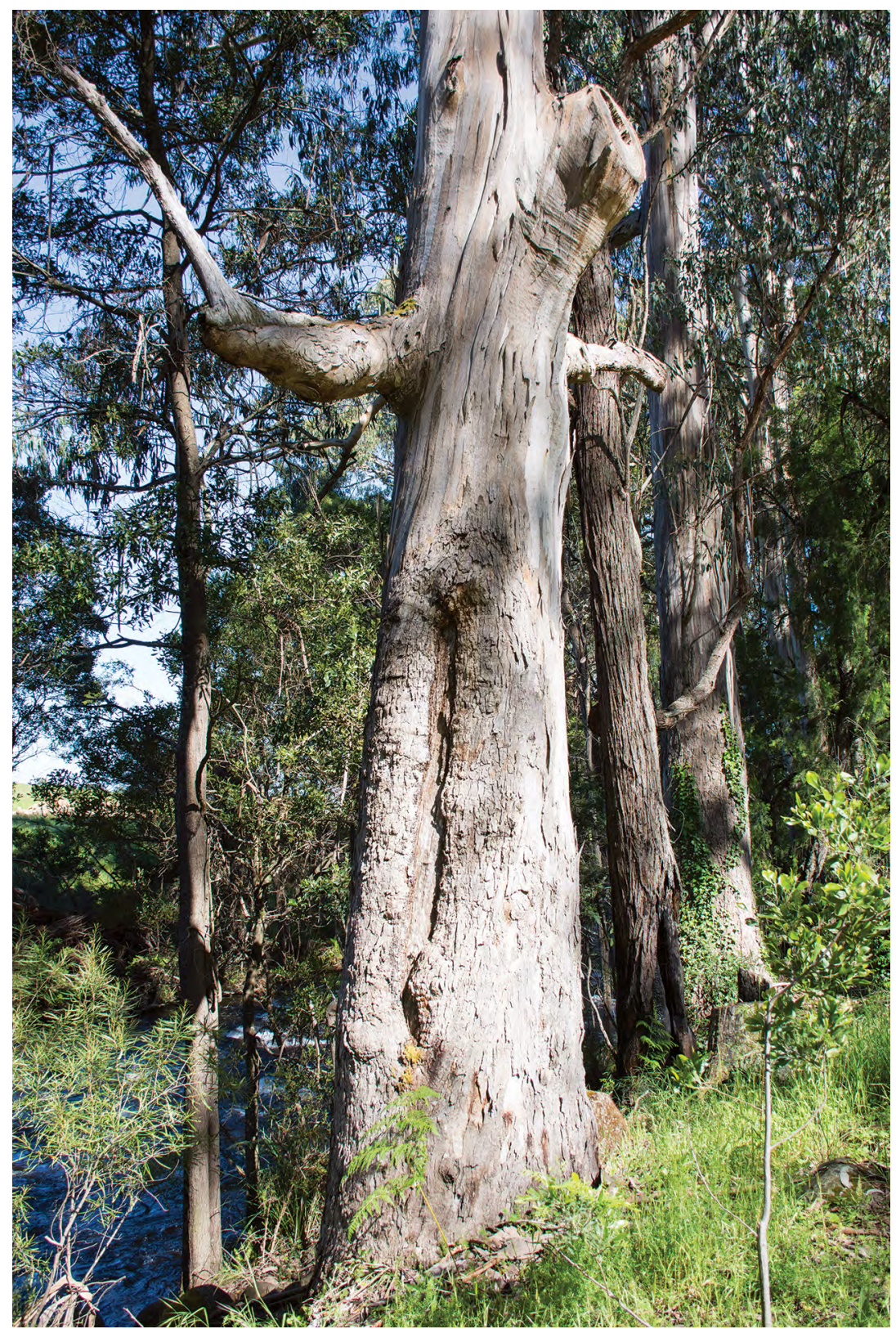

\section{Scar tree}

Source: Photographed by Moorina Bonini. 


\section{Sword grass (Lomandra longifolia)}

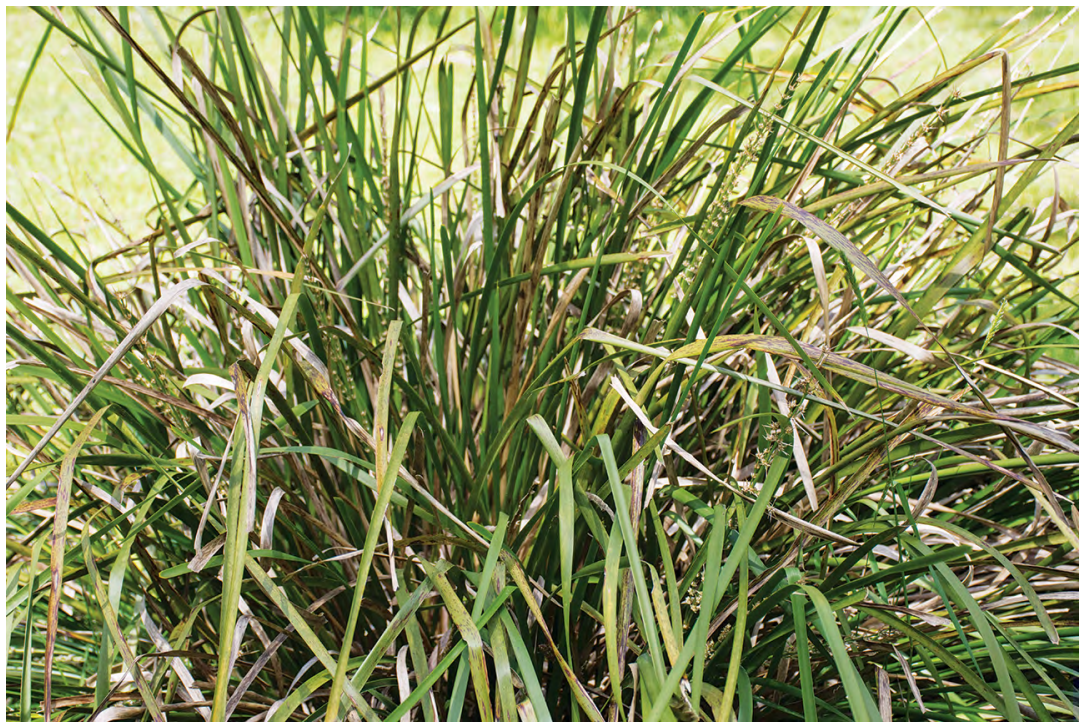

\section{Sword grass}

Source: Photographed by Moorina Bonini.

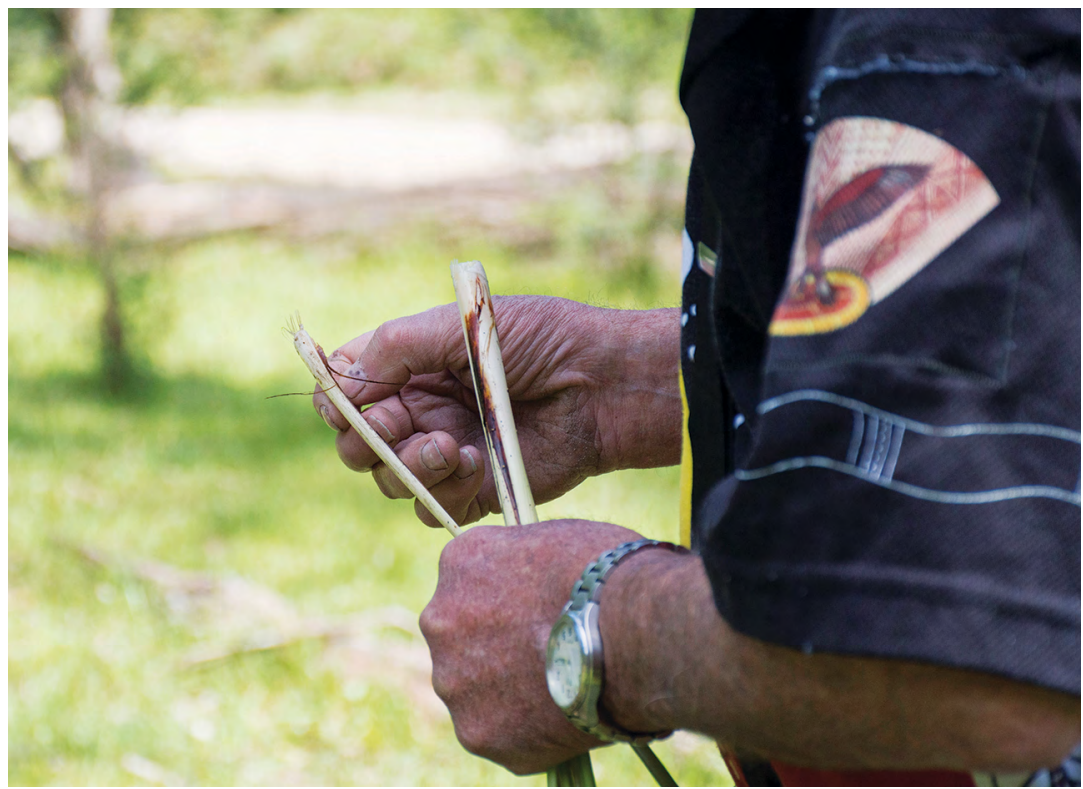

Sword grass-edible white flesh

Source: Photographed by Moorina Bonini. 
This large perennial tussock grass has multiple uses:

This is the sword grass. The edges are nasty; they will rip your hand right open quicker than a knife. I'm going to use a stick to wrap it around and pull until hopefully it will come out. You strip away the brown edges and the white flesh at the bottom you can eat. It tastes nutty, like macadamia nut. You can eat right to the green section.

If you really look around here, there is food. This is also bush medicine; if you cut yourself and bind this onto the wound, it will heal. It is better than white people's medicine, because it heals from the inside out, not from the outside in. It congeals the blood and heals from the inside out; it doesn't leave a scar and doesn't need stitching. ${ }^{59}$

\section{Tea-tree (Leptospermum laevigatum)}

This tall, bushy shrub or small tree grows up to 6 metres tall. It has bark that sheds in strips:

You can break the leaves off this tea-tree and make a drink out of it; hot or cold it is a medicine and the best thirst-quenching drink you can get. ${ }^{60}$

\section{Tree fern (Dicksonia antarctica)}

Tree ferns have an erect stem of up to 15 metres that forms a trunk, from which large green, roughly textured fronds spread, up to 6 metres in diameter. They grow in moist gullies and creek beds, and in high altitude forests: ${ }^{61}$

The tree fern makes your mouth very dry, so to eat the tree fern, you take a little stone and roll it around your mouth, until it increases the saliva. The tree fern tastes like walnut. We keep these little stones all the time in our pocket. If you get bit by a big bull ant, rub this straight on and in seconds the sting goes away; and it works on mosquito bites. ${ }^{62}$

59 Roy Patterson, in conversation with Jennifer Jones, 8-9 November 2016, DS300158-66.

60 Roy Patterson, in conversation with Jennifer Jones, 29 April 2016, DS300148-53.

61 Australian National Botanic Gardens and Centre for Australian National Biodiversity Research, 'Tree Ferns', accessed 29 November 2017, www.anbg.gov.au/gnp/interns-2003/dicksonia-antarctica.html.

62 Roy Patterson, in conversation with Jennifer Jones, 29 April 2016, DS300148-53. 


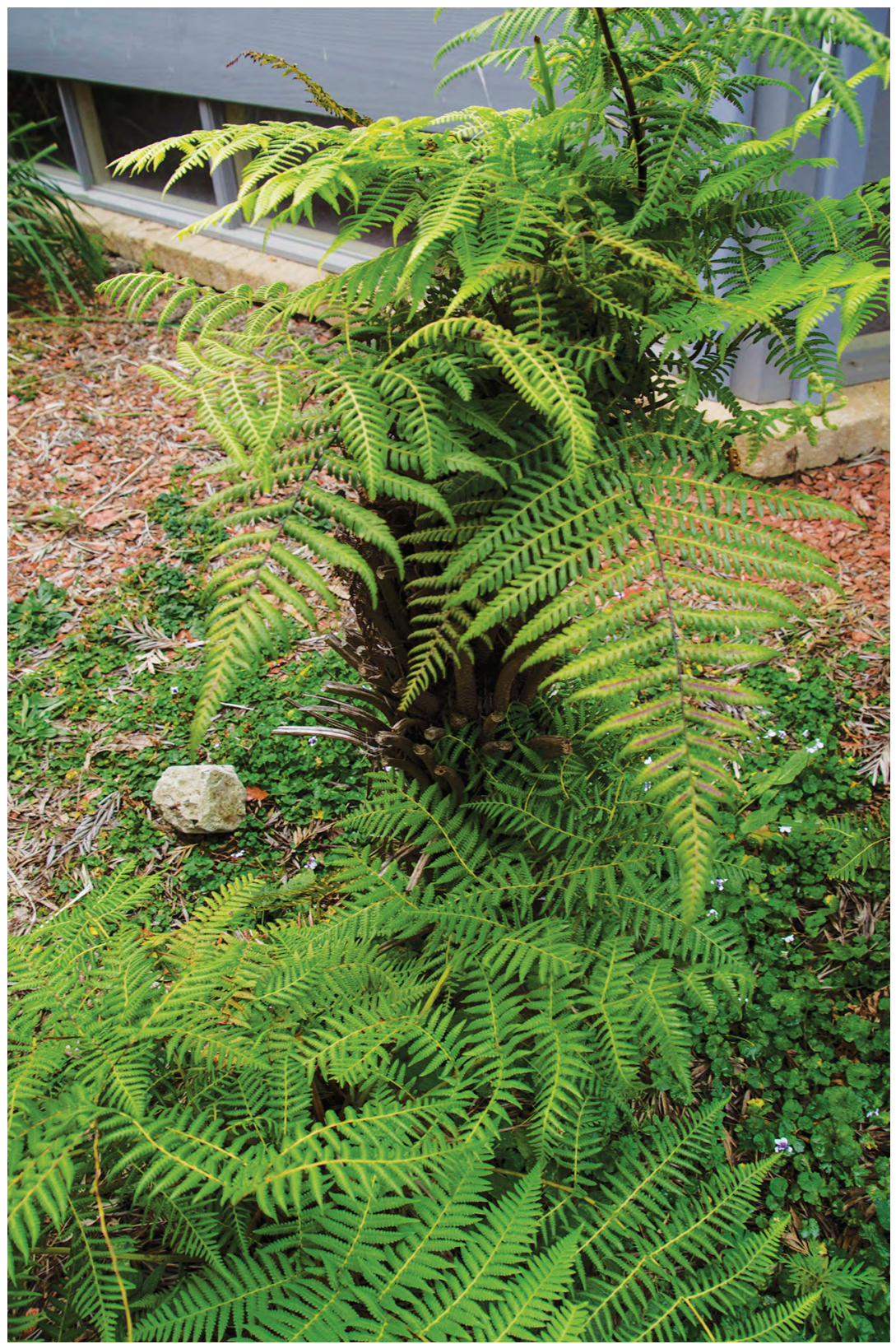

\section{Tree fern}

Source: Photographed by Moorina Bonini. 


\section{Warrigal greens (Tetragonia tetragonioides)}

Also known as native spinach, this scrambling, leafy ground cover is high in antioxidants:

These bigger leaves, you can't eat raw; you have to blanch them and then fry them in butter or oil. Eat that. The small leaf, you can eat it raw and you would swear that you are eatin' bloody cabbage or brussel sprouts. They are a winter plant that needs plenty of water and dies off in the summertime. You go along the beach in south-eastern Victoria and they are growing in the sand down there. Pull the plant out by the root, put it in the ground at your place, and they will grow. It is a winter plant. I was up at Camp Jungai a couple of weeks ago. I finally got in contact with the gardener up there. I said, 'you know that warrigal green over there?' 'Yeah.' I said, 'do not cut it in the winter. It is a winter plant; it grows in the winter.' They said, 'yeah, but it grows into the other plants!' I said, 'well don't be bloody ignorant and don't grow other plants around it!'63

Uncle Roy's stories about bush tucker and bush medicine were designed to change settler attitudes and behaviour. Here he draws attention to the impact of mundane, everyday actions that fail to accommodate the natural features of the native plants. By attributing agency to the plant, and defending its interests, Uncle Roy draws attention to injustices that occur when the vital relationship between humans and plants is overlooked.

Uncle Roy's advocacy for Taungurung Country drew upon his authority as a knowledgeable and experienced Elder. One of our bush tucker excursions, which concluded at a natural spring called Saint Ronan's Well, illustrated this status. The Black Spur was deviated to Saint Ronan's Well when the road was rebuilt 'following a less precipitous route' during the Great Depression. ${ }^{64}$ This permanent water resource marked a stopping point on a traditional walking track used by Aboriginal people. It later served settlers and their horses en route to the goldfields, and still provides fresh, cold water today.

63 Roy Patterson, in conversation with Jennifer Jones, 3 March 2016, DS3001139.

64 Symonds, Healesville, 107. 


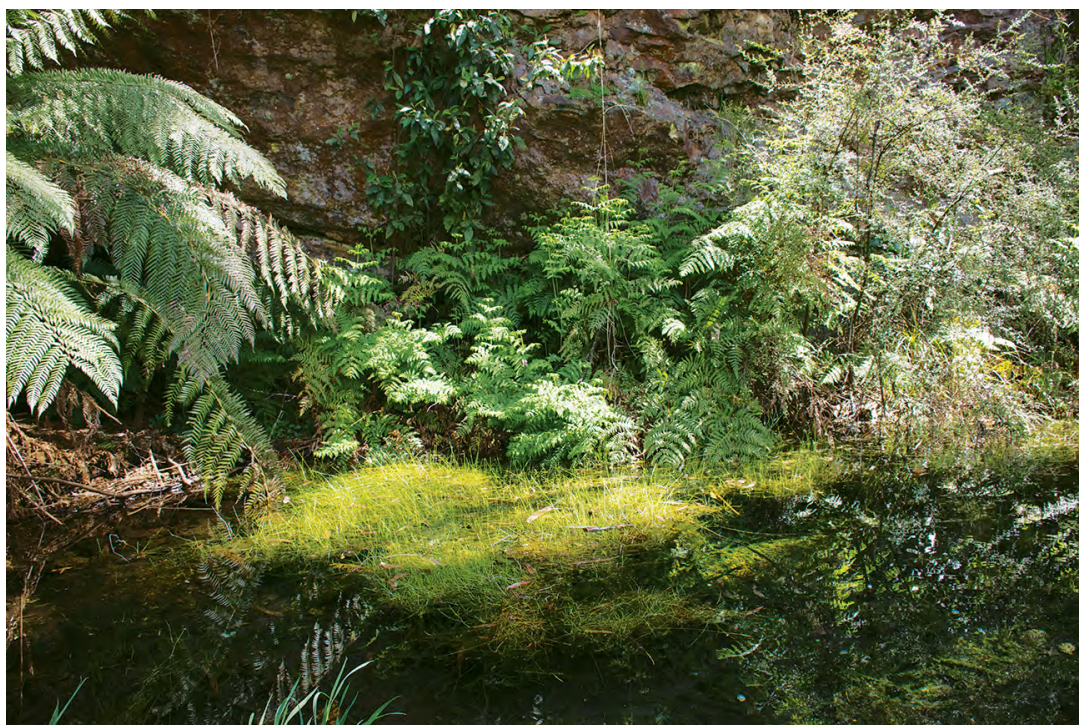

\section{Tree fern at Saint Ronan's Well}

Source: Photographed by Moorina Bonini.

When we pulled up, we found a young Aboriginal mother and her children exploring the pool. It was a breezy day and her son, perhaps five years old, finished his water play and clambered up the rocky hillside with striking independence. Flushed with his achievement and adjusting to the new and daring height, he declined to make his way down when his mother called. As the boy headed further up the incline, the mother gestured towards Uncle Roy and called out: 'You'd better ask the Old Uncle here if you can go further up that hill'. The child turned, diverted by this suggestion and asked, 'why?' She replied, 'because it is his Country!' Satisfied by this logic, the boy clambered down the slope and stood behind his mother's skirts. Uncle Roy nodded with satisfaction. It is his Country, and he knew it:

My history, what I know of it, I can't teach it enough. I got to keep on doin it. The only time I stop is when I can't talk any more. I tell everybody, 'what you learn here today, you go away and teach it'. That is how I am getting my ancestry, my culture, bush tucker, bush medicine around the country. I put it down to this; knowledge cost ya nothing and it is not heavy to carry around. ${ }^{65}$

65 Roy Patterson, in conversation with Jennifer Jones, 15 April 2016, DS300143. 
This text is taken from On Taungurung Land: Sharing History and Culture, by Uncle Roy Henry Patterson and Jennifer Jones, published 2020 by ANU Press, The Australian National University, Canberra, Australia.

doi.org/10.22459/OTL.2020.06 